\title{
How Conflict and Displacement Fuel Human Trafficking and Abuse of Vulnerable Groups. The Case of Colombia and Opportunities for Real Action and Innovative Solutions.
}

\author{
Luz Estella Nagle ${ }^{1}$
}

DOI: $10.21827 / 5 a 86 a 75 a 7 c 5 c 9$

\author{
Keywords \\ COLOMBIA, HUMAN TRAFFICKING, TRAFFICKING OF WOMEN AND CHILDREN
}

\begin{abstract}
Disaffected, impoverished, and displaced people in weak and failing states are particularly vulnerable. Human trafficking exploits social and political turmoil caused by natural disasters, economic crisis, and armed conflict. The exploitation and forced servitude of millions of trafficking victims take many forms. Women and children are trafficked into becoming child soldiers and concubines of illegal armed groups, men, women and children are trafficked into forced labor and sexual slavery, forced to sell drugs, steal, and beg money for the criminals controlling them, and thousands are coerced or forced into a growing black market trade in human body parts. The growth in illegal mining operations by illegal armed groups and organized crime is also fueling conditions of forced labor. Trafficking victims are dehumanized and suffer grave physical and mental illness and often die at the hands of their captors and exploiters. Colombia is particularly afflicted by the scourge of human trafficking. All the elements of modern-day slavery and human exploitation are present in this Latin American state that is struggling to overcome decades of internal armed conflict, social fragmentation, poverty, and the constant debilitating presence of organized crime and corruption. Women's Link Worldwide recently reported that human trafficking is not viewed as an internal problem among Colombian officials, despite estimates that more than 70,000 people are trafficked within Colombia each year. This article examines human trafficking in its many forms in Colombia, the parties involved in trafficking, and the State's response or lack of response to human trafficking. The article also presents innovations that might be effective for combating human trafficking, and proposes that Colombia can serve as an effective model for other countries to address this growing domestic and international human rights catastrophe.
\end{abstract}

\section{Introduction}

Civil strife devastates nations and causes incalculable injuries and deaths, mass displacements, and widespread abuse, killing, rape, and human rights violations.

Professor of Law, Stetson University College of Law. J.D., College of William \& Mary; LL.D., Universidad Pontificia Bolivariana; LL.M., M.A., University of California, Los Angeles. The author wishes to acknowledge the valuable contributions of her Research Assistant Dr. Juan Zarama, LL.M., in the preparation of this article. 
Armed conflict forced people from their homes and thrusts them away from their environment, leaving them vulnerable and easy prey to become objects of exploitation. In the mists of war, human trafficking flourishes. While it is uncertain how many trafficking victims derive from conflict, there is a consensus that the majority of the victims trafficked as a consequence of war are women and children.

War affects vulnerable groups the most because they are the ones that have most often been discriminated against and excluded and disaffected from a nation's wealth, education, policies of protection and prevention. Once so exposed, they are at risk of re-victimisation even in post-conflict scenarios by being exploited and traded by individuals and organised crime within and outside their societies. Amid such chaos and impunity, nations in conflict struggle to balance security and resources. Nations lack policies with proper legal, physical, and social protection mechanisms. They experience a breakdown in economic, social structures, and legal institutions. International obligations are ignored or its application is inadequate and poorly executed. Instability is exacerbated by the massive displacement of people and families that then face stigmatisation and abuse. Women and girls especially fall prey to sexual violence and other forms of victimisation.

To achieve stability and peace, nations devise models of transitional justice. ${ }^{2}$ Most models focus on responsibility for the crimes and abuses perpetrated during the conflict and contain reparation programs for victims of war. While the measures included in transitional justice may achieve compensation and culpability, they often fail to address violations of economic, social, and cultural rights, and they do not tackle the root of the problems or address past injustice. ${ }^{3}$ The result is that nations remain in a phase of low intensity conflict, deprived of meaningful stability and peace. Abuses continue or transform, and violent actors morph into new entities while new violent actors enter an already chaotic state of affairs.

To achieve significant peace and comprehensive justice, ${ }^{4}$ and to secure a nation in which vulnerable groups do not remain at risk of further abuses, the transitional justice framework must be holistic and comprehensive. It should not only address violations considered crimes under international law, but it must also account for the root causes of conflict and provide for the protection of 'all human rights, including economic, social, and cultural rights. ${ }^{5}$ Moreover, true stability and justice can only be achieved if a peace process embraces the participation of women and women's groups in order to 'ensure that women's needs and interests are included' and 'gender-sensitive and gender-inclusive responses to the conflict' are promoted. ${ }^{6}$

This article examines the ordeal of trafficking of women and children and the duty of the Colombian government (GOC) to fulfill both its commitments to its citizens by enforcing its domestic laws, and its obligations to the international community by

2 Transitional justice must provide for the protection of "all human rights, including economic, social, and cultural rights." Cf. Arbour, L., "Economic and Social Justice for Societies in Transition", NYU Journal of International Law and Politics, vol. 40, (1) 2007, 1-27.

3 Louise Arbour stated: "Transitional justice must have the ambition to assist the transformation of oppressed societies into free ones by addressing the injustices of the past through measures that will procure an equitable future. It must reach to-but also beyond-the crimes and abuses committed during the conflict that led to the transition, and it must address the human rights violations that predated the conflict and caused or contributed to it." Cf. Idem, 3.

4 Comprehensive justice must include social justice. According to Louise Arbour the "general understanding of the concept of justice itself," has influenced the marginalisation of the "economic, social, and cultural rights" from transitional justice initiatives. Idem, 4.

5 Idem, 19.

6 SC Resolution 1325, 31 October 2000. 
effecting innovative forms of transitional justice to deal decisively with this growing human rights crisis. Section II offers an overview of the conflict and reveals how international humanitarian law (IHL) and human rights laws have been violated by the various actors, how the governments' policies, legislation, and attempts to demobilise the armed groups are nothing more than a "formal or written" fulfillment of the nation's obligations under international law, and how many laws create a form of "legal conflict" which, among several problems, creates a conundrum of rights difficult to realise and that perpetuate the nation's discrimination against the most vulnerable groups and exposes them to additional violations. We will also see how the growth of displacement and the permanent state of marginalisation and abuse that displaced women and children endure reflect Colombia's persistent violation of its international obligations, and how the "legal" and internal armed conflict creates fertile soil in which human trafficking and exploitation flourishes.

Section III examines the trafficking of women and children due to the armed conflict and the ways in which they are exploited, victimised and abused as combatants, concubines, sex workers and slave labourers. We will examine the impact that illegal armed groups have had on fragmenting the Colombian people into millions of displaced and disaffected beings in such a way as to render them susceptible to human trafficking and related forms of exploitation. This section will also consider the cultural attitudes that persist in Colombia and exacerbate their precarious situation. Section IV addresses Colombia's domestic and international obligations to protect its citizens from human trafficking and important laws and examines several legislative acts and court decisions that impact the conditions of displaced women and children. Section V introduces innovations that can and should be implemented in Colombia, including the development of a human trafficking court and the creation of human trafficking task force. We will also discuss how the international community can assist in finding permanent solutions to the crisis. Section VI offers conclusions.

\section{The Actors and Conditions that Fuel Human Trafficking}

Despite an "official" notice of an end of decades-long internal armed conflict, Colombia endures the most unrelenting armed conflict in the Western world, sustained largely because multiple illegal armed groups evolve and forge alliances with prior enemies for common criminal interests and for resisting "the advance of the security forces. ${ }^{17}$ These actors also pose an increasing security threat to the nation due to their involvement with international terrorist organisations and transnational criminal organisations. ${ }^{8}$

7 BBC News, Jeremy McDermott, Colombia's Criminal Bands Pose New Security Challenge, 25 April 2011, available online at <bbc.co.uk/news/world-latin-america-12804418> (accessed 17 August 2013).

8 Dayton News, Houston Man Gets 101 Months for Trafficking Firearms to Colombia, 16 June 2013, at $<$ yourhoustonnews.com/dayton/news/houston-man-gets-months-for-trafficking-firearms-tocolombia/article_1a588cc9-b088-5846-91d0-a5a194d868cd.html> (accessed 17 August 2013); For a comprehensive report on the trafficking of weapons in Colombia, $C f$. Rand Corporation, Cragin, K. and Hoffman, B., REPORT, Arms Trafficking and Colombia, 2003, available online at <rand.org/content/dam/rand/pubs/monograph_reports/2005/MR1468.pdf> (accessed 17 August 2013). ; MSNBC Online, Lackey, S. and Moran, M., Russian Mob Trading Arms for Cocaine with Colombia, 9 April 2000, available online at <nbcnews.com/id/3340035/ns/newsspecial_coverage/t/russian-mob-trading-arms-cocaine-colombia-rebels/> (accessed 17 August 2013). 
After five decades of violence, Colombia has the highest level of internal displacement in the world. ${ }^{9}$ Innocent civilians have been victims of numerous human rights violations and atrocities including forced displacement and disappearances, inhuman and degrading treatment, extrajudicial and summary executions, sexual violence, forced recruitment of minors, and dispossession of land. Human rights violations are a prevalent occurrence and include violations of the right to life, the right to personal integrity, the right to liberty, the right to security of person, and the right to due process. ${ }^{10}$

Just like the reasons for the armed struggle, the actors have evolved. Between the 1960s and the mid-1980s, left-wing groups fought the GOC over social and economic issues disparities in Colombian society. ${ }^{11}$ During the latter 1980s and 1990s, a new layer of violent groups, well-trained and heavily armed drug cartels and paramilitary groups, emerged to contest for control of the drug markets, to assert hegemony over the civilian population, to steal land in order to create de facto feudal fiefdoms, expropriated natural resources, and corrupted their way into political power. ${ }^{12}$ Yet, throughout the long conflict, Colombia has crafted different initiatives and negotiated numerous peace agreements. Unfortunately, past efforts have been "bilateral" agreements between the government and one of the illegal actors, and many negotiations have ended in failure followed by a resumption of a bloodier conflict. ${ }^{13}$

9 Colombia Reports, Mead, H., Colombia Has Highest Level of Internal Displacement in the World: Study, 29 April 2013, available online at <colombiareports.com/colombia-has-highest-level-of-internaldisplacement-in-the-world-study> (accessed 17 August 2013); BBC News Latin America and Caribbean, Colombia Tops IDMC Internally Displaced People List, 29 April 2013, at <bbc.co.uk/news/world-latin-america-22341119> (accessed 17 August 2013).

10 These rights are expounded in the Inter-American Convention on the Prevention, Punishment and Eradication of Violence against Women, art. 4 (also known as the Convention of Belem do Para), which Colombia ratified on October 3, 1996, available online at <oas.org/juridico/english/treaties/a-61.html> (accessed 17 August 2013).

11 In the 1960s, peasants armed themselves and formed a guerrilla group, the Revolutionary Armed Forces of Colombia (FARC) that to this day continues hostilities against the state. In 1965, National Liberation Army (ELN) was formed. Other smaller leftist guerrilla groups emerged during the 1970s. For an historical overview of these three armed groups, Cf. Nagle, L. E., "Placing Blame Where Blame Is Due: The Culpability of Illegal Armed Groups and Narcotraffickers in Colombia's Environmental and Human Rights Catastrophes", William \& Mary Environmental Law and Policy Review, 29(1) 2004, 13-31.

12 Guerrillas extorted and kidnapped land owners and drug cartels. To defend themselves, land holders created paramilitary groups under the umbrella of the United Self-Defense Forces of Colombia (AUC). These paramilitary groups, allowed to form as legal self-defence militias by Law 48 of 1968 , eventually colluded with the Colombian military to combat the leftist guerrillas, and were often used by the Colombian army as shock troops to go into guerrilla controlled areas prior to the army. In this manner, the Colombian army could claim "plausible deniability" for any human rights violations and potential war crimes committed by the paramilitaries. $C f$. The National Security Archive, National Security Archive Electronic Briefing Book No. 166, Evans, M., Paramilitaries as Proxies, 16 October 2005, available online at <gwu.edu/ nsarchiv/NSAEBB/NSAEBB166/> (accessed 17 August 2013); Colombia Journal, Leech, G., Fifty Years of Violence, May 1999, available online at $<$ colombiajournal.org/fiftyyearsofviolence\#n12> (accessed 17 August 2013). By the end of 1990s, the AUC, FARC and ELN were involved in drug trafficking and other organised crimes and acts of terrorism. Under Plan Colombia, the U.S. supported Colombia's counter-narcotics efforts. However, after November 11, 2001, Plan Colombia included counter-insurgency efforts. Cf. Nagle, L.E., Global Terrorism in Our Own Backyard: Colombia's Legal War against Illegal Armed Groups, Transnational Law and Contemporary Problems, 15(5) 2005, 63-68. In 1997, the U.S. government designated FARC and the ELN Foreign Terrorist Organizations (FTOs), and added the AUC to that FTO list in 2001.

13 The last time the GOC negotiated seriously with the FARC, during the administration of former President Andres Pastrana Arango, the British press reported that British intelligence was tracking 
Despite assertions by the GOC that Colombia is in a post-conflict era and that all is well, the nation continues to be in the throes of an internal armed conflict pitting government forces against heavily armed transnational criminal organisations depicting themselves as leftist guerrillas, violent urban gangs comprised of current and former paramilitary combatants, and drug traffickers protected by private armies of enforcers trained by and sometimes comprised of foreign mercenaries. ${ }^{14}$ Thrown into this evil and volatile brew can be found external transborder criminal organisations from elsewhere in Latin America, from Russia and China, stateless soldiers of fortune, and Islamic terrorist organisations exploiting porous borders and the inability of a central government to maintain and protect the rule of law throughout Colombia's national territory. What is occurring in Colombia is not unlike what is happening in other weak and failing nations in the world where armed conflict and an absence of state security allows low intensity conflict and small wars to persist decade after decade.

\section{II.1. Illegal Armed Groups}

Three major armed groups are responsible for the violence: the left-wing insurgent guerrillas known as the Revolutionary Armed Forces of Colombia (FARC), the National Liberation Army (ELN), respectively, and the successor groups to disbanded right-wing paramilitary forces, known as "BACRIMs" (bandas criminales emergentes). ${ }^{15}$ This last group has emerged as a nationwide threat involved in many different kinds of illegal activities. According to one 2012 report, BACRIMs may have some 8,000 members, and are present in 406 of 1,119 municipalities (46 more than in 2010) and 31

the shipments of surplus weapons and drugs from the FARC in Colombia to Al- Qaeda operatives in Africa, and then to England. Sunday Express, Thomas, G., British Spies Fight to Stop Bin Laden's GunRunning, 9 November 2003. For a thorough analysis of Colombia's obligations to combat domestic and international terrorism, $C f$. Nagle, L.E., supra note 12. After the failure of the 2002 peace negotiations with FARC, the GOC unleashed a ten year military offensive against them. FARC ranks were cut significantly and many senior leaders were killed. Yet, the FARC still threatens the peace and security of the nation with well-planned attacks against military targets, civilian targets, and the country's infrastructure. For a good summary of the various peace negotiations, see Federation of American Scientists, Congressional Research Service, Beittel, J.S., Peace Talks in Colombia, 1 March 2013, available online at <fas.org/sgp/crs/row/R42982.pdf> (accessed 17 August 2013). The GOC is currently in a new round of peace negotiations with the FARC in Oslo, Norway, but many observers contend that the talks are little more than political theater and the FARC has become such a powerful international criminal organisation, with a vast criminal empire of drug trafficking, illegal mining, weapons trafficking, money laundering, and even international cattle rustling, that there is no incentive for the group to put down is arms any time soon. $C f$. Nagle, L.E., "The FARC: Doing What Any Multinational Corporation Would Do-Diversify", International Enforcement and Law Reporter, 28(5) 2012178.

14 Internal armed conflict is defined in Article 3 of the Geneva Convention as "armed conflict not of an international character occurring in the territory of one of the High Contracting Parties." Cf. Geneva Convention Relative to the Protection of Civilian Persons in Time of War, 12 August 1949, 75 UNTS 287. A more contemporary source on the definition of international armed conflict or noninternational armed conflict and the factors that must be present to determine that violence rises to the level of constituting an internal armed conflict can be found in Cullen, A., The Concept of NonInternational Armed Conflict in International Humanitarian Law, Cambridge University Press, Cambridge, 2010, 14.

15 For a broad overview of BACRIMS, see InSight Crime, Perez-Santiago, M., Colombia's BACRIM: Common Criminals or Actors in Armed Conflict?, 23 July 2012, available online at <insightcrime.org/news-analysis/colombias-bacrim-common-criminals-or-actors-in-armed-conflict> (accessed 17 August 2013). 
out of 32 departments in Colombia. ${ }^{16}$ It is stated that 'Bacrims have replaced the Marxist rebels as the primary generators of violence. ${ }^{17}$ These groups are a hybrid of three illegal armed groups: criminal gangs, paramilitary forces, and narcotraffickers, ${ }^{18}$ and are comprised of former paramilitary combatants and sundry criminal actors. ${ }^{19}$ They have been referred to by the Colombia National Police commander as Colombia's greatest current threat to national security. ${ }^{20}$

In addition, combos gangs divide the comunas into zones of control, engaging in a plethora of criminal activities and imposing a form of security, commercial selfregulation and self-imposed justice that for lack of a better description closely resembles a system of feudalism parallel to and independent from government authority. ${ }^{21}$ Nearly all illegal combatant groups maintain both a rural and urban presence and assert control over most regions of national territory to the point that in many areas government security forces are loathe to enter except in force and do not remain very long when they do. These groups pose the greatest threat to the civil society and public security. Together they are responsible for 'the largest number of killings, rape, sexual exploitation, physical and psychological violence, forced displacement, extortion, harassment and threats.' ${ }^{22}$ In rural areas, combos gangs

16 According to a 2012 study done by the Colombian NGO Indepaz Cf. LatAm-Threads, BACRIMS: Colombia's "New" Nightmare, 18 August 2012, available online at <latamthreads.blogspot.com/2012/08/bacrims-colombias-new-nightmare.html> (accessed 17 August 2013). See also Semana, Palomino, S., Las Bacrim tendrían unos seis mil hombres, en seis estructuras, 18 January 2011, available online at <semana.com/nacion/bacrim-tendrian-unos-seis-mil-hombresseis-estructuras/150361-3.aspx>; InSight Crime Ortiz, A., Police: BACRIMs Main Threat to Colombian Security, 26 January 2011, available online at <insightcrime.org/news-analysis/police-bacrims-mainthreat-to-colombian-security> (both accessed 17 August 2013), noting GOC National Police General Oscar Naranjo's statement that the biggest threat to national security is now the activities of the BACRIMS.

17 BBC News Latin America and Caribbean, McDermott, J., Colombia's Criminal Bands Pose New Security Challenge, 25 April 2011, available online at <bbc.co.uk/news/world-latin-america12804418> (accessed 17 August 2013).

18 See Nem Guerra Nem Paz, Ramirez, I.D., Medellín: Los niños invisibles del conflicto social y armado, 160, Children and Youth in Organized Violence, 2011, available online at <uic.edu/orgs/kbc/International/reports/medillin.pdf> (accessed 14 November 2013).

19 Criminal gangs are subordinated to narcotrafficking and paramilitary groups. In Medellín, the gangs are linked to paramilitary groups. Each gang has between 35 and 50 members and most are minors and young adults. Ibid. and Insight Crime 2012, supra note 15; International Crisis Group, Colombia's New Armed Groups, Latin American Report No. 20, 10 May 2007, available online at $<$ crisisgroup.org/ /media/Files/latin-

america/colombia/20_colombia_s_new_armed_groups.ashx> (accessed 17 August 2013); International Crisis Group, Dismantling Colombia's New Illegal Armed Groups: Lessons from a Surrender, Latin American Report No. 41, 8 June 2012, available online at <crisisgroup.org/ /media/Files/latin-america/colombia/41-dismantling-colombias-new-illegalarmed-groups-lessons-from-a-surrender $>$ (accessed 17 August 2013).

20 In January 2011, then Chief of the Colombian Police, General Oscar Naranjo, stated that the BACRIMS were the biggest threat to national security and called the groups emerging criminal bands (bandas criminales emergentes). Cf. In Sight Crime, Ortiz, A., Police: BACRIMs Main Threat to Colombian Security, 26 January 2011, available online at <insightcrime.org/news-analysis/policebacrims-main-threat-to-colombian-security>; Human Rights Watch, World Report 2012: Colombia, 2012, available online at <hrw.org/world-report-2012/colombia> (both accessed 17 August 2013).

21 The Observer, Vulliamy, E., Medellin, Colombia: Reinventing the World's Most Dangerous City, 8 June 2013, available online at <guardian.co.uk/world/2013/jun/09/medellin-colombia-worlds-mostdangerous-city $>$, noting that daily life in the comunas among the combos is like living in a war zone (accessed 20 August 2013).

22 United Nations High Commissioner for Human Rights, Annual Report of the United Nations High Commissioner for Human Rights, Addendum, Report of the United Nations High Commissioner for Human Rights on the situation of human rights in Colombia, A/HRC/22/17/Add.3, 7 January 2013, available 
debilitate the capacity of government entities to function, and their continuing presence erodes public confidence in state authority. ${ }^{23}$

The internal armed conflict is extremely complex, aggravated by drug trafficking and illegal activities that provide highly lucrative revenue streams to keep the groups in existence and their leaders and commanders flush with money stashed in sizable private bank accounts around the world. Until recently, the official position of the Colombian state avoided recognition of the armed conflict as being an "armed conflict" in order to prevent state responsibility that would impose on Colombia certain international obligations under the laws of war. Instead, the government has often referred to the "hostilities" as 'operations against illegal armed groups. ${ }^{24}$

\section{II.2. Internal Displacements and the Comunas}

It has been estimated that as many as five million Colombians have been internally displaced in the course of the long-running internal armed conflict, including refugees fleeing Colombia for shelter abroad. ${ }^{25}$ Displacement is a strategy by armed groups used to maintain territorial control. It is also an expression of power among the actors fighting for territorial control. ${ }^{26}$ Most of the reports indicate that internal displacement is caused by 'the direct or indirect action of illegal armed groups or clashes between such groups. ${ }^{27}$ Displacements typically occur from rural areas to urban centres. Medellín, with between 3 and 4 million residents, has been among the major Colombian cities most heavily impacted by displacements. Since the 1970s, Medellín's population has exploded each decade, with some thirty percent of housing comprising the illegal settlements constructed up in the hillsides above Medellín's urban centre during the last forty years. These settlements are called comunas and began growing when campesinos were forced from their lands in conflict areas and sought refuge in urban environments beginning in the $1950 \mathrm{~s} .^{28}$

The living structures in the comunas were at first little more than illegal squatter camps made from building scraps and pilfered electricity and water. Conditions in the comunas were - and in most cases remain - mostly impoverished, with many comunas still lacking basic necessities. Over time the comunas closer to urban centres became

online at <ohchr.org/Documents/HRBodies/HRCouncil/RegularSession/Session22/A-HRC-2217-Add3_English.pdf> (accessed 17 August 2013).

23 Ibid.

24 International Center for Transitional Justice, Lyons, A. and Reed-Hurtado, M., Colombia: Impact of the Rome Statute and the International Criminal Court, ICTJ Briefing, May 2010, available online at $<$ ictj.org/sites/default/files/ICTJ-Colombia-Impact-ICC-2010-English.pdf> (accessed 17 August 2013).

25 Inter Press Service News Agency, Martínez, H., Colombia: Despite Peace Talks, Forced Displacement Still Climbing in Colombia, 4 June 2013, noting that Colombia has one of the largest displaced populations in the world.

26 Amparo Sánchez, L. and Atehortúa, C., "Narraciones sobre la experiencia del éxodo. El caso del desplazamiento forzado en la comuna" 13, Universitas Bogota (Colombia) 117 July-December 2008, $15-40$.

27 "In $45.6 \%$ of cases, there is no information available about who caused the displacement. $20.5 \%$ of IDPs report that they were displaced as a result of a guerrilla group and $12.7 \%$ as a result of other groups, $10.8 \%$ do not identify the group that led to their displacement, $9.6 \%$ blame counterinsurgent and paramilitary groups, $0.5 \%$ the armed forces and $0.4 \%$ more than one actor. Source: Accion Social, March 2009." Consuelo Carrillo, A., Internal Displacement in Colombia: humanitarian, economic and social consequences in urban settings and current challenges, International Review of the Red Cross, vol. 91 , ed. 875, 2009, 527-546, 529.

28 Amparo Sánchez, L., et al, Desplazamiento forzado en la comuna: La huella invisible de la guerra, CNRR Grupo de Memoria Histórica, Bogota, 2011, 54. 
more permanently developed, and now have utilities provided by the municipal government that are paid for by taxes levied in the wealthy neighbourhoods. ${ }^{29}$ The newest arrivals to the comunas build more squalid and illegal constructions at the outside periphery of the older comunas. This is how the comunas expand, with the most impoverished conditions being at the external edges of the comunas that are the farthest from the municipal presence and municipal services. Naturally, the most squalid areas are the most vulnerable to criminal elements and gang and paramilitary control, although all the comunas are vulnerable to violence.

Statistics have attempted to identify which comunas have been formed by displaced populations and whether the comunas, as a whole, have really been formed by displaced people or are basically communities into which displaced people integrate. The studies have been hypothetical because corroborating the information gathered is difficult due to several reasons. For one thing, armed conflict moves displaced people to any urban environment. The displaced population remains very mobile, and can change from one city to another city. Also, many of the victims of displacement are fearful of being identified to the authorities as such because they feel stigmatised. So they prefer not to report where they are living. This makes it very difficult to determine with certainty which comunas are comprised purely of displaced people. ${ }^{30}$

\section{II.2.1. Forced Recruitments in the Comunas}

The comunas have very little consistent law enforcement presence such that the displaced communities become a crucible of violence and social discontinuity where criminal gangs prey on defenceless people and recruit, coerce or force individuals into joining the illegal groups. The presence of BACRIMS and combos gangs in the comunas contributes to the social collapse, and increases the victimisation of all people living there, but especially women and children. BACRIMS control everything in the comunas and the combos gangs serve as their underlings and foot soldiers doing the dirty work and carrying out criminal activities. In some comunas, the gangs are the only entities that maintain some semblance of order and security. Because the comunas are so forbidding to the civilian government and law enforcement agencies, illegality flourishes.

During demobilisation between 2004 and 2006, youngsters in the comunas were forcibly recruited by paramilitary groups to pose as paramilitaries to show that the paramilitaries were demobilising. ${ }^{31}$ These were just children living in the comunas that had nothing at all to do with paramilitaries. If the families of the children refused to cooperate, the paramilitaries threatened to massacre all the children in the comunas affected..$^{32}$ This elaborate ruse was solely to put on a show to the government that its demobilisation plans were working, while allowing the paramilitaries to preserve their forces as they transformed into BACRIMS. In this way, the demobilisation plans did not help restore internal security at all, but led to the growth of a new security threat in the form of the BACRIMS.

29 Some would say that instead of the government taking decisive steps to return displaced populations back to their places of origin once those areas are deemed secure, it has created a large welfare state that constitutes a classic case of wealth redistribution and encourages populist politics.

30 Cf. Del Pilar Bohada R., M., "Desplazamiento forzado y condiciones de vida de las comunidades de destino: el caso de Pasto, Nariño", Revista de Economía Institucional, 12(23), 2010, 259-298.

31 Amparo Sánchez, L., supra note 28, 128, noting that the paramilitary group Cacique Nutibara, was the first to forced displaced children into the demobilisation process.

32 Ibid. 
Forced recruitment of children into combos and BACRIMS ${ }^{33}$ occurs throughout the displaced communities. ${ }^{34}$ This activity constitutes another form of human trafficking, since the children forced into the illegal groups are made to carry out many illegal activities, like drug trafficking and larceny, and serve as intelligence gatherers. Young virgins, both boys and girls, are forcibly recruited by the gangs to be prostitutes, charging Johns 7 million Colombian pesos to have them. ${ }^{35}$ Statistics to support these reports are difficult to gather because there is a great deal of fear among those who could provide accurate details about this human trafficking activity.

\section{II.2.2. Urban Displacement}

BACRIMS and combo gangs have increasingly involved growing problems of urban displacements, in which people are forced from one comuna into another in an attempt to escape gang-related violence, predatory crime, and forced recruitment into the gangs. ${ }^{36}$ Forced urban displacement constitutes another form of human trafficking. Urban displacement been recognised as a problem only since 2003. Before that time, it was hidden by other social problems and undetected by government authorities due to its dimensions and effects. In the cities, this hidden effect was deepened because it occurred in limited spaces within the comunas. Moreover, only members of the affected communities were aware of urban displacement because denouncing it provoked direct threats from the perpetrators. ${ }^{37}$

While urban displacement is now an acknowledged problem, the authorities seem less concerned about the welfare of the inhabitants who are victimised by urban displacement and more preoccupied by the possibility of 'contamination and diffusion' into other urban areas. ${ }^{38}$ Also, urban displacement appears to be occurring with government complicity, in direct violation of several civil and human rights. In a recent incident in a notorious comuna in Medellín, a man was told by the leader of the local combo that he had to surrender his house to the leader because the location was strategically important to the combo for maintaining control of the comuna. ${ }^{39}$ The man, who lived in the home for five years after the government had settled him there, refused to turn his property over to the combos and went to the local government

33 Idem, 126.

34 Forced recruitment has taken place in the comunas are far back as 2000 when guerrilla forces still had a presence in the comunas before being forced out by the paramilitaries. Forced recruitment of children under the age of fifteen is a violation of Article 4(3)(c) of Additional Protocol II of the Geneva Conventions. The Convention on the Rights of the Child, which Colombia has ratified, also fixes the minimum recruitment age of fifteen. However, it should be noted that when Colombia ratified the 1989 Convention on the Rights of the Child on Jan. 28, 1991, it filed a reservation to art. 38 (in regards to the fact that Colombia considers 18 years the minimum age for taking part in armed conflicts).

35 Dario ADN, Atehortúa, D.C., 'Combos' de Medellín inducen a niñas vírgenes a la prostitución, 8 November 2012, available online at <diarioadn.co/medell\%C3\%ADn/miciudad/prostituci\%C3\%B3n-y-delitos-acosan-a-adolescentes-1.32216> (accessed 18 August 2013).

36 In 2011, these groups became primarily responsible for the highest number of population displacements. The groups identified as being chiefly to blame are Las Águilas Negras, Los Rastrojos and Los Machos. Cf. Internal Displacemet Monitoring Centre, Internal Displacement Global Overview 2011: People Internally Displaced by Conflict and Violence, April 2012, 56, available online at <internal-displacement.org/publications/global-overview-2011> (accessed 18 August 2013).

37 Amparo Sánchez, L., supra note 28, 17.

38 Ibid.

39 El Colombiano, Arango, R.M., Desplazadas otras 18 personas en la comuna 13, 9 June 2013, available online esplazadas_otras_18_personas_en_la_comuna_13.asp> (accessed 18 August 2013). 
official's office to complain. He returned to his home in the late afternoon to discover that official and several officers of the SIJIN ${ }^{40}$ were there waiting to help him pack his house up to move. One can only wonder how is it that the combos have the power to force people from their homes with the backing and active support of the government.

\section{II.2.3. Victimisation of Women in the Comunas}

A significant number of displaced women in the comunas become displaced due to sexual violence which 'is under-reported, as women are ashamed to report incidents when attempting to register as displaced. ${ }^{41}$ The conflict hits particularly hard displaced women who are forced to assume all family responsibilities after the killing of their husbands or partners.

Women (and children) of the comunas are coerced, trafficked or forced due to the conditions in which they live to become prostitutes in a burgeoning domestic sex tourism industry fuelled by foreign visitors, or become forced labourers in manufacturing and agriculture production. They are also forcibly recruited to become combatants and child soldiers, ${ }^{42}$ consorts and camp followers for male combatants and, at times, human weapons to be sacrificed in terrorist attacks or as expendables used to clear mine fields. ${ }^{43}$ There is also strong evidence that Colombia has emerged since 2005 as one of the top five country destinations for organ trafficking. ${ }^{44}$

Women and children in the comunas are particularly vulnerable to false opportunities to get out. Most have been uprooted from their rural origins and the children of displaced families now grow up in the comunas without any orientation to the places from which their families came. Violence against women by abusive male partners is a constant problem, and children are often seen as an impediment to surviving in the urban landscape. Human traffickers are adept at exploiting the social conditions rampant in the comunas. Young girls and women who have no other means of support are extremely impressionable when traffickers come into the comunas to offer jobs in fashion modelling or working as domestic house staff. It is the

40 The SIJIN is the National Police's Section of Criminal Investigation. See the official webpage at <policia.gov.co/portal/page/portal/UNIDADES_POLICIALES/Comandos_deptos_policia/com ando_depto_meta/especialidades/Sijin> (accessed 18 August 2013).

41 A 2007 study of four Colombian cities by the Colombian government's Ombudsman Office found that " $18 \%$ of displaced women identified sexual violence as a direct cause of displacement." $C f$. Refugees International, Colombia: Displaced Women Demand Their Rights, 16 November 2009, available online at <refintl.org/policy/field-report/colombia-displaced-women-demand-theirrights $>$ (accessed 18 August 2013). It is estimated that seventy-six percent of abused women do not denounce their abusers for fear of violence and retaliation against family members. $C f$. Dario ADN, Redaction Medellín, Gobernación reconoce existencia de prostitución en Antioquia, 30 May 2013, $<$ diarioadn.co/medell\%C3\%ADn/mi-ciudad/prostituci\%C3\%B3n-en-antioquia-1.62198> (accessed 18 August 2013).

42 Article 4(3)(c) of Additional Protocol II of the Geneva Conventions prohibits the recruitment of children under the age of fifteen or allowing them to take part in hostilities.

43 Social workers in rural Colombia are alarmed that children are taken to replenish the ranks of adult fighters who are killed or leave the FARC. Cf. CNN World, George, W.L., Colombia's Indigenous Communities Caught in The Middle, 2 August 2011, available online at <cnn.com/2011/WORLD/americas/08/02/colombia.violence/index.html> (accessed 18 August 2013).

44 Cf. Mendoza, R.L., Colombia's Organ Trade: Evidence from Bogotá and Medellín, Journal of Public Health, 18(4) 2010, 375-384 (noting that "the organ trade in Colombia is generally open, brokered, and without price competition and provisions for vendors' postoperative care, which help attract many foreign buyers. These factors also increase the vulnerability of vendors to unscrupulous third parties."). 
same modus operandi used around the world where human traffickers prey on the misery and desperate economic circumstances of others.

\section{II.3. Impact of Demobilisation on Human Trafficking}

By many accounts, the demobilisation effort undertaken by the GOC has been a fiasco. While carefully avoiding recognising the internal armed conflict for what it is, the GOC has undertaken at different times several strategies to reduce hostilities and bring about peace in a troubled land by negotiating demobilisation plans with belligerents.

\section{II.3.1. Demobilisation of Armed Groups}

In July 2003, the GOC proposed a peace agreement with the AUC in a bill known as the Law of Alternative Punishment ${ }^{45}$ under which the AUC would agree to 'total cessation of hostilities and gradual demobilisation.' In exchange, the GOC offered immunity during negotiations, and it agreed to work with Congress to grant them special treatment regarding their prosecution and punishment for war crimes, crimes against humanity, and drug trafficking offences." ${ }^{46}$ The bill was met with strong opposition in Congress and defeated. More than a year later, the Congress passed Law 975 of $2005,{ }^{47}$ known as Justice and Peace Law. This law began the process of transitional justice in Colombia.

The demobilisation process of 30,000 members of paramilitary groups, namely the AUC, under the framework of the Justice and Peace Law ${ }^{48}$ (JPL) enacted in 2005, was presented as the endpoint of the armed conflict and a "point of departure for transitional justice' 49 because it would reinstate into the civil society thousands of illegal armed combatants and not-state actors operating outside the law and 'contribute to achieving national peace and other provisions for humanitarian agreements.' The JPL was intended to pacify and stabilise the national territory by offering a path to reintegration for paramilitary combatants and a means for restitution for victims. Even though the JPL is considered a vital component for transitional justice in Colombia, its implementation has been controversial, unreliable and flawed. ${ }^{50}$ The JPL was supposed to bring to justice the main leaders of the paramilitary forces, but as pointed out by the UNHCR, 'as of September 2012, out of thousands of

45 El Abedul, Proyecto de ley de alternatividad penal, Proyecto de Ley Estatutaria 85 de 2003 Senado, at <elabedul.net/Articulos/Nuevos/alternatividad_proyecto_de.php> (accessed 18 August 2013).

46 Domac, Chehtman, A., REPORT, The ICC and Its Normative Impact on Colombia's Legal System October 2011, available online at <domac.is/reports/> (accessed 18 August 2013),

47 Ley 975 de 2005, Diario Oficial No. 45.980 of 25 July 2005, available online at <secretariasenado.gov.co/senado/basedoc/ley/2005/ley_0975_2005.html> (accessed 18 August 2013).

48 Ibid.

49 Centro Nacional de Memoria Histórica, Ansari, E. et al., Historical Memory in Colombia: The work of the group de Memoria Historica, Report of the International Economic Development Program, 2012, available online

<centrodememoriahistorica.gov.co/descargas/IEDP_2012_COLOMBIA_Human_Rights_Report_ GMH.pdf> (accessed 18 August 2013).

50 The JPL and the demobilisation law provided a "two-track" process or legal framework for demobilising. All members of illegal armed groups "could demobilize collectively or individually under Law 782/2002 (which was extended and modified in December 2006). Law 782 helped deserters with their reintegration into civil society. In contrast, the JPL promoted alternative sentences and penalty reductions to demobilised combatants who confessed to major crimes committed while under arms. "In July 2006, Colombia's Constitutional Court upheld the constitutionality of the JPL, but limited the scope under which demobilising paramilitaries could benefit from reduced sentences." Cf. Beittel, J.S., supra note 13, 10. 
possible defendants, only 14 people have been sentenced' for crimes involving serious human rights crimes. ${ }^{51}$ This shortfall is due to a significant lack of resources and inadequate staffing within the Justice and Peace Unit that was established under the law to process victims' claims. ${ }^{52}$ The demobilisation process under the JPL during 2004 to 2006 also triggered the emergence of the BACRIMs.

Regrettably, the JPL may have been misused by corrupt officials to create a political smoke-screen, allowing the investigations against top paramilitary commanders to proceed at a snail's pace or to be derailed all together so that paramilitary commanders could seek extradition to the U.S. to face drug trafficking charges and negotiate plea bargains rather than face much stiffer human rights charges in Colombia. ${ }^{53}$ Many thousands of individuals may also have received government benefits for falsely claiming to be paramilitary combatants as part of a corrupt scheme carried out by former Peace Commissioner Luis Carlos Restrepo, a charge Mr. Restrepo has vehemently denied..$^{54}$ Moreover, many of the weapons that were turned in were not even functional, suggesting that fully serviceable weapons have been cached away for the benefit of the BACRIM groups that have emerged from the demobilisation process.

Reintegration from the perspective of Colombian society has been difficult as well. Much of the population takes a dim view toward welcoming former paramilitaries back into civilian life when so many of them are responsible for human rights abuses and terrorising communities. Finding themselves as social outcasts rather than as prodigals welcomed back into the fold of the social fabric, the former illegal armed combatants now struggle to exercise territorial control in certain regions and are also responsible for widespread criminal activities and violence. If successful demobilisation of belligerent forces is a marker to indicate post-conflict conditions, then it is difficult to accept that such a condition exists in Colombia at this time. ${ }^{55}$

\section{II.3.2. Demobilisation of Women and Child Soldiers}

Women and children have been largely left out of the GOC's demobilisation process due to many factors that combined render them more vulnerable to human trafficking. Of the nearly 41,000 men, women and children who have been demobilised, between

51 Supra note 22, 17. In one particular proceeding from April 2011, the Mampuján case, the Colombian Supreme Court ordered financial compensation and collective reparations for more than 1,400 victims of forced displacements and murders in three Colombian communities.

52 International Crisis Group, Correcting Course: Victims and the Justice and Peace Law in Colombia, Latin American Report No. 29, 30 October 2008, available online at <crisisgroup.org/home/index.cfm?id=5753> (accessed 18 August 2013).

53 Nagle, L.E., Better a Jail Cell in the United States: Using Extradition to Avoid Criminal Accountability in Colombia, International Enforcement Law Reporter, vol. 28, ed. 11, 2012, 397.

54 Cf. Colombia Reports, Alsema, A., Medellin's Ex-Mayor Says Fake Paramilitaries Demobilized, 21 February 2012, available online at <colombiareports.com/medellins-ex-mayor-says-fakeparamilitaries-demobilized $>$, noting that the "AUC demobilized 35,000 men while before the peace process they officially only had 20,000 members," and reporting that "[t]housands of demobilized members have since rearmed". Cf. InSight Crime, Stone, H., Fake Colombian Demobilization Stories Explain Rise of BACRIMs, 11 March 2011, available online at <insightcrime.org/news-analysis/fakecolombian-demobilization-stories-explain-rise-of-bacrim> (both accessed 18 August 2013), noting that this falsified demobilisation plan led to the growth of BACRIMS.

55 Supra note 24, noting: "Colombia has a long history of using amnesties to address the demobilization of guerrilla members and some paramilitary groups. The peace-versus-justice debate has been loaded with rhetoric and manipulation. The official discourse avoids the use of 'armed conflict' and instead has cast the debate in terms of 'illegal armed groups' and 'terrorists,' thereby avoiding questions of state responsibility. To date, no serious public discussions have occurred to outline the various stakeholders' positions." 
6 and 9 percent are women. ${ }^{56}$ As the Colombian public becomes more knowledgeable about the role women played as combatants, either voluntarily or otherwise, there is little sympathy for them as former members of illegal armed groups. Consequently, many are victimised a second time when they demobilise because they carry the stain of having been fighters, concubines, perpetrators of violence, and propagandists against the Colombian state and against the Colombian people. ${ }^{57}$ Former female combatants are not seen in a sympathetic light. They are treated as pariahs because they transgressed "traditional gender norms." 58 They are shunned by their families and by their communities. Many can never return to their places of origin because of the things they did as illegal armed combatants. They have been victims of sexual violence, rape, forced abortions, forced sterilisation and contraception. Some have had children with guerrilla-fighters and many Colombian citizens do not want the State to be responsible for caring for the acute mental and physical needs of female combatants or for the children they now have. Most of the demobilised women cannot return to their places of origin due to well-founded fears of reprisals from former armed combatants. ${ }^{59}$ One report notes that while demobilised women were born in all but one of Colombia's 32 departments, 85 percent sought the relative security of anonymous urban neighbourhoods and comunas in Bogotá and Medellín rather than returning home to their families and native surroundings. ${ }^{60}$

Former female combatants are also stigmatised because they have transgressed traditional gender norms and for most the prospect of returning to their families is out of the question, due to the harshly paternalistic and patriarchal nature of Colombian society. One recent paper put the situation succinctly:

The traditional association of women with homemaking and their important family role of raising children and supporting their husbands, makes Colombians stigmatize and be afraid of female ex-combatants. With a past surrounded by weapons and death, to civilians, demobilized women have apparently lost their femininity and the established patterns of their behaviour in society; then, people perceive them as a double danger, not only for the uncertainty they bring into society, but also

56 Statistics vary significantly depending on the source. 'Unofficial data illustrates that from November 2003 to August 2006, out of the 31,664 combatants collectively demobilized, $6 \%(1,911)$ were women (ODDR, 2011); meanwhile, official sources increase this number to $9.2 \%$ or 2,930 women who collectively demobilized (Policía Nacional de Colombia, 2008). Considering women who individually demobilized, from August 2002 to March 2011, from among 23,402 combatants individually demobilized, 18.5\% (4,333) were women (ODDR, 2011). This data is doubtful after comparing it to the number of women active and mistreated in armed groups, situation that for some analysts can only be explained by the assertion that women are not properly counted in the demobilization] process.' See UCLA: Centre for the Study of Women, Giraldo, S., Demobilized Women Combatants: Lessons from Colombia, 3 February 2012, 7. See also Schwitalla, G. and Dietrich, L.M., "Demobilisation of Female Ex-Combatants in Colombia", Forced Migration Review, vol. 27, ed. 58, January 2007, available online at <fmreview.org/FMRpdfs/FMR27/39.pdf > (accessed 18 August 2013).

57 Schwitalla, G. and Dietrich, L.M., "Demobilisation of Female Ex-Combatants in Colombia", Forced Migration Review, vol. 27, ed. 58, 58-59, January 2007, available online at <fmreview.org/FMRpdfs/FMR27/39.pdf> (accessed 18 August 2013).

58 Ibid.

59 Ibid.

60 Ibid. 
because of the threat they represent to social order in important aspects like family care, children's education, sexuality and reproduction. ${ }^{61}$

Reports also indicate that child soldiers were largely left out of the demobilisation process, because government officials "failed to enforce the handover of children as a condition for AUC paramilitary groups to enter the process, leaving thousands of children formerly associated with the AUC unaccounted for and without any protection." 62 According to one analysis, of the 31,671 AUC combatants that demobilised, only 391 minor combatants were processed between 2003 and 2006. ${ }^{63}$

The alternatives for integrating children back into civilian life include the following options:

- Transitory Home: a temporary location where the child is assessed for a more permanent arrangement that may better fit his or her needs.

- Specialised Care Centre: a second phase during which a more comprehensive evaluation is better targeted to the special needs of the child.

- Juvenile Hospice: a third phase where the child receives job and life skills training for insertion back into society.

- Care in a socio-familiar unit: controlled foster family care until age $18 .^{64}$

Although this and other structured reintegration programs are well-intentioned, the crucial need for long-term follow up care and monitoring is largely absent. Of greater concern, however, is that many female child soldiers fall through the cracks of specialised support programs. ${ }^{65}$ When girls leave the ranks as soldiers, they frequently experience conflicting feelings of betrayal of their 'protective' group. At the same time, they may become a target for retaliation by those very same armed groups. Many are no longer welcome in their families and their communities.

\section{II.4. Conflict or Post-Conflict and Why It Matters}

Why is it so important for Colombia to convince the nation and the world that it is entering a "post-conflict" era? Non-conflict or post-conflict status is crucial in order to attract new investment from overseas, to stabilise the business climate, to maintain the flow of aid and loans into the country, and to create the appearance that commerce is secure, and the civil society is protected. Well-publicised military gains against

61 Giraldo, S., "Demobilized Women Combatants: Lessons from Colombia", Thinking Gender Conference 22, Ann. Grad. Student Res. Conf., UCLA Ctr. for the Study of Women, Feb. 3, 2012, 7.

62 Watchlist on Children and Armed Conflict, No One to Trust: Children and Armed Conflict in Colombia 4, April 2012, available online at <watchlist.org/wordpress/wp-content/uploads/WatchlistColombiaReport-LR.pdf $>$ (accessed 18 August 2013).

63 Ibid.

64 Obra Social Fundación "La Caixa", Castillo-Tietze, D., "Las Niñas Soldados: En Busca de la dignidad arrebatada", November 2008, available online at <obrasocial.lacaixa.es/deployedfiles/obrasocial/Estaticos/pdf/Coop_Internacional/Sensibilizacion /Les_nenes_soldat_es.pdf $>$ (accessed 18 August 2013).

65 Ibid. 
guerrilla groups and the killing of key rebel leaders, promote the appearance of a Colombian state achieving post-conflict security. ${ }^{66}$

Between the 1960s and into the 1990s, there is general agreement that the international law applicable to the conflict in Colombia was Common Article 3 of the Geneva Convention of $1949^{67}$, Additional Protocol $\mathrm{II}^{68}$ and international customary law. It was not until the late 1990s, however, that the international community reached a consensus that Colombia was indeed engaged in an internal armed conflict, because there was a well-armed group, under the direction of a leader, and in control of a portion of Colombian territory. These three conditions met the threshold for internal armed conflict under Protocol II, which afforded extra protection to the civilian population. The GOC long insisted that such was not the case, and the difficult aspect with the type of struggle that Colombia is in today, particularly with regard to the BACRIMS, is whether we are still going to apply Common Article 3, Protocol II, and customary international law to protect those civilians even though the GOC asserts that the conflict is over.

The GOC would argue that the country is in a state of post-conflict because the two prominent illegal armed groups, the paramilitaries and the FARC, seem to have demobilised, demilitarised and entered into a peace process. That argument is but a formality. The reality is that Colombia is still engaged in an armed conflict, and while the political elites may believe that there is no more armed conflict, the residents of the comunas and inhabitants of many rural municipalities would be hard pressed to believe otherwise.

In an armed conflict, all parties in the conflict are responsible for upholding the laws of war. The laws of war were developed to protect human life in armed conflict. By trying to convince the civil society and the international community that the armed conflict is over, the GOC is essentially taking away the legal protections for civilians under international law. What is the incentive for the GOC to do this? Some would argue that the motivation is development-driven. Foreign investment is attracted back to most post-conflict countries if the security situation is believed to have stabilised. The concern, however, is that the Colombian state could be viewed as placing economic incentives and investment before the welfare, safety, and rights of Colombia's civil society.

After many years of denial during the Uribe government, the current president, Juan Manuel Santos, officially recognised - shortly after taking office - that there has indeed been an armed conflict in Colombia for some time ${ }^{69}$ sustained by the presence of domestic and transnational criminal organisations that profit from the trafficking of drugs, weapons, and human beings and any other profitable illicit activity. While the security situation is improved in some areas of the country, especially the neighbourhoods in which the political elites reside, ongoing criminality has created a chronic environment of social insecurity.

Another measure to determine the difference between conflict and post-conflict conditions concerns, of course, is the number of internally and externally displaced people that remain uprooted from their places of origin. A measure of stability is a

66 E.g. Human Rights Watch, "World Report 2011: Colombia", January 2011, available online at $<$ hrw.org/world-report-2011/world-report-2011-colombia> (accessed 14 June 2013).

67 Geneva Conventions Relative to the Laws of War, 1950, 75 UNTS 135, Art. 3.

68 Protocol Additional to the Geneva Conventions of 12 August 1949, and Relating to the Protection of Victims of Non-International Armed Conflicts (Protocol II), 1977, 1125 UNTS 609, Art. 6.

69 Insight Crime: Organised Crime in the Americas, Stone, H., The War of Words Over Colombia's Conflict, May 2011, available online at <insightcrime.org/insight-latest-news/item/884-the-war-ofwords-over-colombias-conflict> (accessed 22 June 2013). 
demonstration that property ownership is relatively secure, but such is not the case in Colombia where displacement translates to a catastrophic loss of land ownership and title.

The GOC has long had a significant problem with proving land ownership among peasant families in rural areas. In fact, one of the issues over which the UNHCR is most critical is that the manner in which the GOC is implementing its land restitution agenda to address displacements is not consistent with international standards. ${ }^{70}$ This is one of the goals put forth for 2013, along with helping to strengthen the technical support capacity of those institutions, responsible for implementing the Victims and Land Restitution Law. ${ }^{71}$

Another indicator that Colombia is not in a post-conflict era is the frequency of armed assaults on journalists, ${ }^{72}$ human rights advocates and community organisers, ${ }^{73}$ educators, trade unions, ${ }^{74}$ indigenous and Afro-Colombian representatives, ${ }^{75}$ advocates for displaced people, and the victims of paramilitary violence seeking land restitution and justice. ${ }^{76}$

Bolstering the appearance that Colombia has entered a post-conflict era includes promoting both domestic and foreign tourism. The GOC has encouraged the tourism industry to trade on the imagery for which Colombia is well known-tropical beaches, lush jungles, emerald Andean highlands, upscale hotels, casinos and a cosmopolitan nightlife, and especially beautiful and exotic Colombian women. While this is not a result of armed conflict and displacement, per se, both contribute to the conditions that have forced women and children into sex tourism.

Trading on beauty has become hyper-sexualised, and the Internet is now crowded with sex tourism businesses, some based in the United States, specialising in making all inclusive arrangements for foreign men to come to Colombia to meet beautiful

70 UNHCR, 2013 UNHCR Country Operations Profile-Colombia Working Environment, 2013, available online at <unhcr.org/pages/49e492ad6.html> (accessed 7 June 2013).

71 Ibid.

72 Colombia currently ranks fourth on the Committee to Protect Journalists 2013 Impunity Index. See CPJ Blog, Getting Away with Murder, 2 May 2013, available online at <cpj.org/reports/2013/05/impunity-index-getting-away-with-murder.php>. Recent reports by the CPJ stress that BACRIMS are now emerging as a serious threat to journalists in Colombia. See CPJ Blog, Otis, J., In Colombia, 'Bacrim' Pose New Press Threat, 24 May 2013, available online at <cpj.org/blog/2013/05/in-colombia-bacrim-pose-new-press-threat.php> (both accessed 18 August 2013).

${ }^{73}$ Human Rights First, Human Rights Defenders in Colombia, available online at $<$ humanrightsfirst.org/our-work/human-rights-defenders/colombia>. See also Human Rights First, Baseless Prosecutions of Human Rights Defenders in Colombia in the Dock and Under the Gun, February 2009, available online at <humanrightsfirst.org/2009/02/01/baseless-prosecutions-ofhuman-rights-defenders-in-colombia-in-the-dock-and-under-the-gun $>$ (both accessed 18 August 2013).

74 'From 2005 to 2010, 265 trade unionists were murdered in Colombia; 51 trade unionist were murdered in Colombia in 2010; 29 were murdered in 2011. In the last two decades, more than 2,800 Colombian trade unionists have been assassinated with a near total rate of impunity (over 95\%).' See USLEAP: US Labor Education in the Americas Project, Background: Violence Against Trade Unionists in Colombia, available online at <usleap.org/usleap-campaigns/colombia-murder-andimpunity/more-information-colombia/background-violence-against-> (accessed 24 June 2013).

75 Washington Office on Latin America, Racism, Violence Continue for Afro-Colombians, 7 February 2013, available online at <wola.org/commentary/racism_violence_continue_for_afro_colombians> (accessed 27 June 2013).

76 E.g. Relief Web, OAS Report: IACHR Regrets Murder of Colombian Activist and Urges State to Protect Community Leaders Advocating for Rights of Those Displaced by Armed Conflict, 19 April 2013, available online at reliefweb.int/report/colombia/iachr-regrets-murder-colombian-activistand-urges-state-protect-community-leaders (accessed 18 August 2013). 
Colombian women (or whatever else they desire), for companionship and adult entertainment. ${ }^{77}$ The tourism packages include rental apartments, exclusive night club reservations, excursions and female escorts (known as prepagos), ${ }^{78}$ to serve as companions for the duration of the vacation. ${ }^{79}$ The adult entertainment industry has become such a significant and lucrative component of Colombian tourism and nightlife that women from all levels of Colombian society, many with college educations and coming from wealthy families, are drawn to the opportunity of profiting from consorting among foreign men with money to spend. ${ }^{80}$ It is a powerful draw for women anxious to improve their life situation in a society that is so heavily materialistic that prostitution becomes an activity that is considered by some as being chic and a valid way to get ahead in life. ${ }^{81}$

This is not to infer that efforts are not in place to combat sex tourism, at least in Cartagena, where awareness campaigns to discourage sex tourism, particularly involving minors, have been underway for a decade. In one instance, when a foreign tourist entered a hotel with a twelve year old girl he had encountered at the La Boquilla beach through the referral of a taxi driver, he was welcomed with a sign reading, 'La Muralla Soy Yo' (I Am the Wall). The receptionist, suspicious, made the tourist aware that it is a serious crime in Colombia to sexually exploit children, and that perpetrators may be charged for up to 25 years in prison. The man, who barely spoke any Spanish, let the girl go home. ${ }^{82}$

The non-government organisation, Fundacion Renacer, ${ }^{83}$ has been an instrumental actor in the city of Cartagena, in particular, where the organisation has managed to win the collaboration of government officials and private entities to encourage local business to adopt codes of conduct. ${ }^{84}$ Very significantly, Fundacion Renacer has been

77 See for example the website of one business called Adult Vacations Cartagena, available online at <cartagenaadultvacations.com> (accessed 24 June 2013). The promotion reads, 'If you aren't "bringing sand to the beach" we have beautiful Colombian girls of your choice looking to get out of the house to help share in your vacation adventures!' The company is based in San Francisco, California.

78 A term for pre-paid women escorts that has now become a widely used expression to denote prostitutes that cater to well-heeled clientele.

79 Slate, Jiménez Jaramillo, J., Colombian Escorts Go High-Class—and High-Tech, 19 April 2012, available online at <slate.com/blogs/browbeat/2012/04/19/colombian_prostitutes_websites_and_twitter_ feeds_why_escorts_in_colombia_have_gone_high_tech.html > (accessed 18 August 2013), noting that 'The infrastructure behind the prepago industry is massive and problematic, with ties to both corporate and drug money. Telenovelas about escorts and drug lords, like Sin Tetas No Hay Paraíso (No Heaven Without Tits), have proliferated in Colombia in recent years, gathering huge audiences.'

80 These Internet businesses are supposed to conform to a standard of privacy for the escorts working for them. However, only children younger than 13 years of age are covered. The notice, found on the Cartagena Adult Vacations website states: 'The Rule imposes certain requirements on operators of websites or online services directed to children under 13 years of age, and on operators of other websites or online services that have actual knowledge that they are collecting personal information online from a child under 13 years of age (collectively, "operators"). If human trafficking of children includes minors up to 18 years of age, then these internet businesses operating in Colombia and from outside Colombia appear to be in violation of international human trafficking norms.'

81 Terra Networks, Cacho: Con el Modelo de Mujer Hipersexualizada Ganaran las Mafias Sexuales, 7 June 2010, available online at <noticias.terra.com/noticias/cacho_con_el_modelo_de_mujer_ hipersexualizada_ganaran_las_mafias_/act2364163> (accessed 18 August 2013).

82 Foreign Affairs Trade and Development Canada, Stolen Youth: Combatting Sexual Exploitation of Children in Cartagena, Colombia, 14 December 2010, available online at <acdi-cida.gc.ca/acdicida/ACDI-CIDA.nsf/eng/ANN-1117114059-MKN> (accessed 18 August 2013).

83 Fundación Renacer, webpage, available at < fundacionrenacer.org> (accessed 24 June 2013).

84 Foreign Affairs Trade and Development Canada 2010, supra nt. 85. 
able to convince the Hotel Owners Association that child sex tourism is not only a human rights violation, but it is also not good business. ${ }^{85}$ The awareness campaign also includes schools, police officers, beach vendors, restaurant owners, and taxi drivers, among others. The organisation has played a central role in the wording of Law 1329 of 2009, which amends a previous law, Law 599 of 2000, and provides sentences of between 14 to 25 years in prison for facilitating, organising, or participating in any form of sex trade or exploitation of an underage child, or for demanding or soliciting sex with a minor. ${ }^{86}$

\section{Trafficking of women and children due to armed conflict.}

The trafficking of women and children for labour and sexual exploitation is a multibillion dollar crime worldwide. While no certain figures can be determined, it is reported that trafficking for forced labour ${ }^{87}$ alone generates US $\$ 31.6$ billion in illegal profits annually, ${ }^{88}$ whereas trafficking for sex exploitation is about US\$33.9 billion each year. ${ }^{89}$ Forced displacement due to internal armed conflict, creates favourable conditions for human trafficking and puts at risk the most vulnerable groups: women and children. According to the Internal Displacement Monitoring Centre, at the end of 2012, an estimated 28.8 million people were displaced worldwide, with Colombia topping the list with between 4.9 and 5.5 million internally displaced people (IDPs).$^{90}$ More than half of the IDPs are under age eighteen. ${ }^{91}$ In 2012 alone, more than 230,000 people were displaced in Colombia due to internal armed conflict and organised criminal activities. ${ }^{92}$ Among women and children displaced in Colombia, nearly all become potential targets of human traffickers and the illegal armed groups that prey on women and children to fill the ranks of armed combatants as well as to provide sources of income.

International observers are nearly in lockstep in their observations of conditions in Colombia; that, firstly, the situation of human trafficking is out of control, that women

85 Ibid.

86 Ley 1329 de 2009, Diario Oficial No. 47.413 of 17 July 2009.

87 Forced labour is defined by the ILO as 'all work or service which is exacted from any person under the menace of any penalty and for which the said person has not offered himself voluntarily.' International Labor Organization Convention No. 29 Concerning Forced or Compulsory Labor, 1930, 39 UNTS 55, Art. 2(1)1.

88 UNODC: United Nations Office on Drugs and Crime, REPORT, Global Report on Trafficking in Persons 2012, 68 available online at <unodc.org/documents/data-andanalysis/glotip/Trafficking_in_Persons_2012_web.pdf> (accessed 14 June 2013).

89 Belser, P., "Forced Labor and Human Trafficking: Estimating the Profits", ILO Special Action Programme to Combat Forced Labour (SAP-FL), Working Paper, DECLARATION/WP/42/2005, March 2005, 14, available online at <digitalcommons.ilr.cornell.edu/forcedlabor/17> (accessed 13 June 2013).

90 Colombia Reports, Mead, H., REPORT, Colombia Has Highest Level of Internal Displacement in the World: Study, 29 April 2013, available online at <colombiareports.com/colombia-has-highest-levelof-internal-displacement-in-the-world-study/>; also, Norwegian Refugee Council, Albuja, S. et al, Global Overview 2012 People Internally Displaced by Conflict and Violence, April 2013, 9, available online at <nrc.no/arch/_img/9674184.pdf $>$. Another report places Colombia second behind Sudan in the number of internally displaced people. John Hopkins The Protection Project, REPORT, A Human Rights Report on Trafficking in Persons, Especially Women and Children, September 2010, available online at <protectionproject.org/wp-content/uploads/2010/09/Colombia.pdf> (all accessed 14 November 2013).

91 Watchlist on Children and Armed Conflict, No One to Trust: Children and Armed Conflict in Colombia, April 2012, 4, available online at <watchlist.org/wordpress/wp-content/uploads/WatchlistColombiaReport-LR.pdf $>$ (accessed 18 August 2013).

92 Norwegian Refugee Council, Albuja, S. et al, Global Overview 2012 People Internally Displaced by Conflict and Violence, April 2013, p. 9. 
and children from displaced communities are most vulnerable, that the GOC is not able to combat the human trafficking occurring through the national territory and that officials of the GOC appointed to combat human trafficking and other human rights abuses are not providing reliable or accurate reports and statistics on how bad the situation actually has become. Lastly, that the GOC has been accused of conducting illegal activities against human rights workers, Supreme Court judges, journalists, and political rivals. ${ }^{93}$

Illegal armed groups use women as instruments and objects of war. Most are victims between 15 and 30 years old..$^{94}$ Many are recruited by force and become sexual slaves. In many cases, the illegal armed groups control women through physical and psychological violence as a way to injure the enemy. This is achieved through the dehumanisation of the victim, exploiting vulnerabilities of the family, and stoking terror in the community. ${ }^{95}$ Women lack guarantees to denounce abuses because few believe them or because denouncing the aggressors is a longer process than it takes for the aggressors themselves to find out who actually went to the authorities. ${ }^{96}$

Women and children who are caught up as victims of human trafficking in Colombia are subjected to the physical and mental methods of control that characterise victimisation and domestic abuse in other parts of the world. These may include:

- Using Intimidation: Victims are subjected to violence directed at them or around them by witnessing violence against others. This occurs through using looks, actions, gestures, smashing objects and destroying the victim's belongings, and by displaying weapons in a menacing manner.

- Using Emotional Abuse: Victims are humiliated and ridiculed, dehumanized by the use of demeaning words and actions, and playing mind games.

- Using Isolation: One of the most effective means of asserting total control of trafficking victims is to remove them from outside human contact, controlling all movements, limiting or preventing any mental stimulus like reading materials and television and using jealousy among victims to justify actions.

- Minimizing Denying and Blaming: Traffickers make light of the abuse and do not take the concerns of victims seriously. They shift responsibility for the victims' circumstances onto the victims, making them feel as if it is their fault.

93 Colombia Reports, Theintz, G., Critical Report on Colombia Human Rights Presented to UN Council, 24 March 2010), available online at <colombiareports.com/critical-report-on-colombia-human-rightsreport-presented-to-un-council/> (accessed 18 August 2013), citing Ana Maria Rodriguez, a representative of the Colombian Jurist Commission, who asserted that there was enough documentation to 'demonstrate the government's responsibility in the illegal activities of the Colombian Security Agency (DAS) against human rights defenders, magistrates of the Supreme Court, political opposition and journalists.'

94 El Tiempo, Zambrano, A., El expediente de los crimenes sexuales de las Farc, 6 June 2013, available online at <eltiempo.com/justicia/ARTICULO-WEB-NEW_NOTA_INTERIOR-12851726.html> (accessed 18 August 2013), noting a 2012-2013 report, 'Violencia basada en género (VBG)' that concluded that there was an evident "instrumentalization of women as tools and objects of war".

95 Verdadabierta, Moro, B., Mujeres: víctimas con derecho a la verdad, justicia y reparación, available online at <verdadabierta.com/nunca-mas/41-violencia-contra-mujeres/230-mujeres-victimas-con-derechoa-la-verdad-justicia-y-reparacion> (accessed 27 June 2013).

96 Zambrano, A. supra nt. 97. 
- Using Children: Traffickers threaten the relationship of women to their children in order to gain control and power over them.

- Using Male Privilege: Macho tendencies in Colombian culture have long persisted. Traffickers use such behaviour, to control women and children, for example, making victims servants and submissive.

- Using Coercion and Threat: Victims are subjected to constant threats of violence, punishments, and deprivations in order to be controlled. ${ }^{97}$

\section{III.1. Women and Children as Forced Combatants, Concubines, and Sex Workers}

\section{III.1.1. Women and Children as Forced Combatants and Concubines}

Women have been trafficked into the ranks of illegal armed groups for many years. There is an abundant amount of documentation and testimonials by former female combatants, who suffered years of serious sexual abuse and other forms of forced servitude. In many cases of women forced into illegal armed groups, including both guerrillas and paramilitaries, ${ }^{98}$ an alarming number become unwilling concubines. ${ }^{99}$ This constitutes a clear violation of the Fourth Geneva Convention and Additional Protocol I, which is intended to protect women from sexual violence, including rape, assault, and forced prostitution. ${ }^{100}$ One former female FARC member interviewed, told how nearly all female "recruits," regardless of age, were forced to be sex slaves servicing male guerrillas "in an effort to maintain morale among the male troops and avoid the security risk that comes with the men venturing into town to consort with civilians. ${ }^{101}$ Those women that have the misfortune to become pregnant are subjected to forced abortions or induced labour before full term, after which the baby is left to die. ${ }^{102}$ Moreover, the UNHCR has reported that illegal armed groups often run prostitution rackets in areas under their control in order to generate revenue and use brothels as a means to extract intelligence from enemy clients." 103

97 E.g. Help Guide, Domestic Violence and Abuse: Signs of Abuse and Abusive Relationships, available online at <helpguide.org/mental/domestic_violence_abuse_types_signs_causes_effects.htm> (accessed 14 June 2013).

98 US Office on Colombia, Understanding Colombia Series: The Impact of War on Women, available online at <usofficeoncolombia.org/understanding_colombia/pdf/women.pdf> (accessed 14 June 2013).

99 CNN Freedom Project: Ending Modern Day Slavery, Horrific Use of Child Soldiers Rising in Colombia, Report Finds, 15 October 2012, available online at $<$ thecnnfreedomproject.blogs.cnn.com/2012/10/15/horrific-use-of-child-soldiers-rising-incolombia-report-finds $>$ (accessed 18 August 2013).

100 Hathaway, O., et al., "Which Law Governs during Armed Conflict? The Relationship between International Humanitarian Law and Human Rights Law", Minnesota Law Review, vol. 96, 2012, 1883, citing Additional Protocol to the Geneva Conventions of 12 August 1949, and Relating to the Protection of Victims of International Armed Conflict, 1977, 1125 UNTS 3, Art. 76, and Geneva Convention Relative to the Protection of Civilian Persons in Time of War, 1949, 75 UNTS 287, Art. 27.

101 Americas Forum for Freedom and Prosperity, Phillips, A., FP: Why Women Turn to the FARCand How the FARC Turns on Them, 3 June 2012, available online at <americas-forum.com/whywomen-turn-to-the-farc-and-how-the-farc-turns-on-them/> (accessed 18 August 2013).

102 Ibid.

103 Nacla Online, Ballvé, T., Colombia: Aids in the Time of War, 2011, available online at $<$ nacla.org/article/colombia-aids-time-war> (accessed 13 June 2013), noting that forcing sex workers to have unprotected sex garners a higher price, and that such tactics of intelligence gathering places the sex slaves in further peril as enemy spies. It is also a crime in Colombia for any group, 
With regard to the trafficking of children into armed conflict, while statistics are very unreliable and produced for sometimes less then objective purposes, it has been estimated that some 14,000 children in the last decade were pressed into armed groups involved in the Colombian conflict, ${ }^{104}$ in direct violation of Article 4(3)(c) of Protocol II prohibiting the recruitment of children under the age of fifteen or allowing them to take part in hostilities, and the Convention on the Rights of the Child, which fixes a minimum recruitment age of fifteen and which Colombia has also ratified. This places Colombia fourth behind Myanmar, Liberia, and the Republic of Congo in the number of children soldiers recruited. ${ }^{105}$ Some current reports indicate that the number of children being forcibly recruited into the ranks of armed groups is still rising. Children are trafficked into illegal armed groups through kidnapping, but some who live in desperate circumstances are coerced by the promise of food and shelter. ${ }^{106}$ Child soldiers are deprived of their "right to freedom, self-determination, right to a family, [and] are forced to adopt a denigrating life style, fundamentally unjust for the exercise of their fundamental guarantees" 107 under both Colombian and international law.

The findings of a recent, and apparently controversial study, produced by a law school dean in Bogotá, indicate that sixty-nine percent of child soldiers are under 15 years of age and as young as 8 years old. ${ }^{108}$ Child soldiers are known as "little bees"109 who fulfil a variety of roles, including placing land mines (or in some cases being used as human detonators), transporting weapons and explosives, clearing minefields, conducting reconnaissance, and working as servants and sex slaves of guerrilla and paramilitary combatants. There have been reports that child soldiers are also forced to participate in summary executions, torture, assassinations, kidnappings, and armed attacks against civilian targets. ${ }^{110}$ In addition, child soldiers are considered expendable renewable resources. In one particularly heinous act, a ten year old boy was tricked by FARC guerrillas into riding a bicycle packed with explosives into a military checkpoint where it was detonated by remote control. ${ }^{111}$

including the Colombian armed forces, to use children in intelligence gathering roles. Ministero de Defenso Nacional, Decreto Numero 128 (2003) (Colombia), available online at $<$ dafp.gov.co/leyes/D0128003.htm> (accessed 24 June 2013), Art. 22.

${ }^{104}$ UNICEF, Armed groups in Colombia stealing childhood from girls and boys alike, 25 August 2008, available online at < unicef.org/infobycountry/colombia_45354.html> (accessed 18 August 2013), noting that in 2003, '7,000 children in Colombia were in the ranks of armed groups, and an additional 7,000 were involved in urban militias.' See also Rethmann, A., "Condenados al Silenciojovenes excombatientes en Colombia" Independencias - Dependencias - Interdependencias, VI Congreso CEISAL, 2010, Toulouse, Paper, available online at $<$ halshs.archives-ouvertes.fr/halshs-00503128/> (accessed 25 June 2013). While many children report to have voluntarily enrolled, purported consent is involved with regard to underage children. Ramirez Barbosa, P.A., "El recrutamiento de menores en el conflict armado colombiano", Rev. de Derecho Penal y Criminalogia, vol. 31, Jan-Jun 2010, 115.

${ }^{105}$ Watchlist on Children and Armed Conflict, Colombia's War on Children, February 2004, available online at <watchlist.org/reports/pdf/colombia.report.pdf> (accessed 17 June 2013), 26.

106 CNN Freedom Project: Ending Modern Day Slavery 2012, supra nt. 103

107 Ramirez Barbosa, P.A. 2010, supra nt. 108.

${ }^{108}$ CNN Freedom Project: Ending Modern Day Slavery 2012, supra nt. 103

109 Escobar, V., "Reclaiming the "Little Bees" and "Little Bells": Colombia's Failure to Adhere to and Enforce International and Domestic Law in Preventing Recruitment of Child Soldiers", Fordham International Law Journal, vol. 26, 2002-2003 , 785-870, 810, noting these child soldiers have been dubbed as "little bees" for their ability to 'sting before their targets realize they are being attacked' and that Paramilitaries also use young children, called "little bells," to serve as back-up troops, spies, and patrolmen in their home regions.

110 Ramirez Barbosa, P.A. 2010, supra nt. 108.

111 Watchlist on Children and Armed Conflict, Report to Ombudsman's Office, No. 017, 5/12/03: Colombia's War on Children, February 2004, available online at $<$ watchlist.org/reports/pdf/colombia.report.pdf> (accessed 17 June 2013), 8 and 26 et seq. 


\section{III.1.2. Women and Children as Forced Sex Workers}

The GOC currently promotes a new image for Colombia as a fabulous tourism destination. Regrettably, while there is so much to see and do in Colombia, some Colombian cities have become notorious for sex tourism, even though all prostitutionrelated activities are illegal in Colombia. ${ }^{112}$ While prostitution is a part of adult entertainment and a high octane nightlife, perhaps in no other Colombian city is the exploitation of women and children more pernicious than in Cartagena, where over the last decade, the city has seen an explosion of the hotel and tourism sectors, promoted by feverish investment by wealthy tourists mainly from the United States and Europe.

The improved economic conditions have not trickled down to the local poor communities however, and many of the poor and displaced living in Cartagena's slums are invariably drawn into the city's sprawling sex industry. ${ }^{113}$ An average of 650 minors are believed to be forced into the sex trade at any given time, and while sex tourism is illegal, ${ }^{114}$ the law does not stop a high number of service workers, waiters, doormen, taxi drivers, and bus operators competing for commissions to deliver clients to Cartagena's many sex clubs and brothels. ${ }^{115}$ Facilitated in great part by the development of the Internet, foreign tourism for sex with both girls and boys ${ }^{116}$ is highly priced, in great part due to the misconception that children are free of STIs. ${ }^{117}$

Cartagena is now ground zero in Colombia for predators coming from around the world to have sex with children. ${ }^{118}$ But Cartagena is just one destination for an illegal industry that exploits over 35,000 children in Colombia every year. ${ }^{119}$ In Bogotá, for instance, girls thirteen and fourteen years old are approached in schoolyards, and drawn into sex slavery for foreign businessmen. ${ }^{120}$ According to a 2010 report produced by Fundacion Renacer, Fundacion Esperanza, the Instituto Distrital de Turismo and the Secretaria de Integracion Social, Internet websites and chat rooms that cater to

112 Codigo Penal de Colombia Art. 213, available online at $<$ derechos.org/nizkor/colombia/doc/penal.html> (accessed June 14, 2013).

113 IRIN Plus News, Colombia: Sex Tourism Booming on the Caribbean Coast, 18 November 2008, available online at <irinnews.org/report/81528/colombia-sex-tourism-booming-on-the-caribbean-coast> (accessed 18 August 2013).

114 Codigo Penal de Colombia Art. 219, available online at $<$ derechos.org/nizkor/colombia/doc/penal.html> (accessed June 14, 2013).

115 IRIN Plus News 2008, supra, nt. 119.

116 In 2010, the Children of the Andes foundation described the appalling story of an eight year old boy who became victim of sex trade. Accompanying his twelve-year old sister to the beach, where she would meet tourist-clients, and subsequently to hotel rooms, he would duck under the bed while his sister was being abused by the client. On one occasion, the client offered to pay extra for touching the young boy. Aware of his family needs, the young boy thus became another victim of Colombian sex trade. See Silent Victims: Children of the Andes Spring Newsletter 2010, Speaking Out against the Sexual Exploitation of Children in Colombia, 20 March 2010, available online at <childrenoftheandes.org/news.php/321/silent-victims-spring-newsletter-2010> (accessed 18 August 2013).

117 According to Fabian Cardenas, regional director of Fundacion Renacer, 'People come here from other countries or cities to have sex with children because they think it is safe.' IRIN Plus News 2008, supra, nt. 119.

118 Ibid.

119 Silent Victims: Children of the Andes Spring Newsletter 2010 Supra, nt. 123.

120 El Tiempo, Malaver, C., Asi opera el "turismo" sexual con menores: Taxistas, 'tarjeteros' y empleados de hoteles informarian a turistas en donde encontrar a menores, 8 December 2010, available online at $<$ eltiempo.com/colombia/bogota/as-opera-el-turismo-sexual-con-menores/8554540> (accessed 18 August 2013). 
international sex tourists provide explicit details on locations in Colombia where to have sex with minors. ${ }^{121}$

Indigenous children continue to be particularly vulnerable to predatory sex servitude. One pernicious form is called "a hunt" (caceria), in which indigenous children are kidnapped for days and believed to be forced into sex trade and drug trafficking. ${ }^{122}$ Often these children never return to their communities. ${ }^{123}$

\section{III.1.3. Cultural Attitudes toward Female Victims}

As has happened to demobilised female combatants, Colombian women in general are vulnerable to chauvinist, patriarchal, and patronising attitudes by Colombian men that are deeply rooted and difficult to confront in the society. ${ }^{124}$ In Colombia, gender violence is an accepted fact of life. Most victims are girls between 5 to 14 years of age, ${ }^{125}$ and most do not file charges against their male perpetrators because intimidation is so overwhelming. The notion that a female family member is nothing but property to use as the family patriarch sees fit is deeply entrenched and very resistant to change, particularly in agrarian family life where such conduct is rarely exposed to prosecution under the law. ${ }^{126}$

There is also a high level of shame and guilt imposed on female victims by the society and many in law enforcement have the attitude that if a woman is beaten or raped, she must have done something to bring this on herself. Knowing that many law enforcement officers do not take violence or sexual exploitation against women seriously, perpetrators have a feeling of impunity for their conduct. ${ }^{127}$

The stress displaced women and children feel is compounded by the social divides that already separate Colombians between the "haves" and the "have-nots." Those on top control everything, while those who are impoverished have no hope of rising any higher than their born station in life. Displacement only increases the sense of being disaffected and stigmatised by the circumstances of life, thrown into chaos by armed conflict and continuing violence. ${ }^{128}$ Colombia's already difficult social roles between males and females are amplified by internal armed conflict. ${ }^{129}$ Indeed, it has been

121 Some businessmen even plan their official business around their sexual activities, Ibid.

122 El Tiempo, Efe, Denuncian rapto de niños indígenas para la explotación sexual en Colombia, 2 January 2011, available online at <eltiempo.com/colombia/otraszonas/ARTICULO-WEBNEW_NOTA_INTERIOR-8719440.html> (accessed 18 August 2013).

123 Ibid.

124 Tolton, L., "Normalizing Wife Abuse in Colombia" in: Majstorović, D. and Lassen, I., eds., Living with Patriarchy: Discoursive Constructions of Gender Subjects across Cultures, John Benjamins Publishing Company, Amsterdam, 2011, 39.

125 Centro de Estudios de Opinion, Carrillo Urrego, A., Los Delitos Sexuales en Colombia, entre el Desconcierto y la Impunidad, 4, available online at <aprendeenlinea.udea.edu.co/revistas/index.php/ceo/article/viewArticle/1376> (accessed 26 June 2013).

${ }^{126}$ As a judge, I was once charged to hear the case of a peasant for sexual assault on his daughter, and render sentence. His attitude was that his daughter was his property because that was the way things have always been in his society. He literally could not understand why what he had done was against Colombian law because the formal codes of law were utterly foreign to his way of life.

127 The GOC Attorney General's Office recently stated: 'Despite efforts for public officers to work in a more gender sensitive manner, they continue to be clumsy towards victims in their response. There are still prejudices which are difficult to eradicate.' See Targeted News Service Universidad Nacional de Colombia, Women Have Been War Scenarios, 6 March 2013, available online at $<$ unal.edu.co/ndetalle/article/women-have-been-war-scenarios.html> (accessed 18 August 2013).

128 Nagle, L.E., "Global Terrorism in Our Own Backyard: Colombia's Legal War against Illegal Armed Groups", Transnational Law and Contemporary Problems, vol. 5, ed. 10, 2005, 15.

129 UNIFEM, Meertens, D., REPORT, Final Report of the Program on Peace and Security: Tierra, derechos $y$ género: Leyes, politicas y prácticas en contextos de guerra y paz, 2006, available online at 
argued that the high number of female victims of the Colombian armed conflict is itself a manifestation of a patriarchal culture, magnified in the crucible of war. ${ }^{130}$ Gender violence has also become both a military and a strategic method and objective of warfare and assault that is a continuation of aggressions and violations that occur during civilian life. ${ }^{131}$ In the context of armed conflict, the female body becomes a weapon or a tactical target used in such a way as to terrorise civilians, to acquire territory by forcing displacements, to punish the enemy, to claim as a war prize, and to exploit for sexual gratification and labour servitude. ${ }^{132}$

\section{III.2. Organ Trafficking}

In addition to sex tourism, Colombia has become an important destination for medical tourism. ${ }^{133}$ Many legitimate hospitals and medical groups are taking advantage of Colombia's close proximity to the United States to advertise the cost benefits of going to Colombia for elective procedures in plastic surgery, weight reduction, cardiovascular care, and organ transplants. ${ }^{134}$ One organ transplant company operating in Colombia even set up a call centre in Arizona, ${ }^{135}$ and on a webpage discussing organ harvesting, one posting from Colombia said,

'I give my knowledge to obtain organs for needy patients, here in Colombia of legal form according to the constitution for foreigners they can call me 3107134300 cellular' ${ }^{136}$

Demand for organs results in a supply chain that begins in displaced communities throughout Colombia, and this flourishing black market in illegally harvested organ and body parts, such as kidneys and corneas, lures foreigners to Colombia to obtain

$<$ ictj.org/sites/default/files/ICTJ-Brookings-Displacement-Gender-Colombia-CaseStudy-2012-

English.pdf $>$ (accessed 18 August 2013).

130 Andrade Salazar, J.A., "Women and Children, the Main Victims of Forced Displacement", Orbis, vol. 16, ed. 5, 2010, 28-53, 36. See also Garcés, E., Colombian women: the struggle out of silence, Lanham: Lexington Books, 2008, 9.

131 Opinión Jurídica, Restrepo Yepes, O.C., El Silencio de las Inocentes? Violencia Sexual a Mujeres en el Contexto del Conflicto Armado, 6, January-June 2007, available online at $<$ redalyc2.uaemex.mx/articulo.oa?id=94501106> (Accessed 18 August 2013), 93, noting that 'it is the same model of men against women that keeps encouraging the acts of domination of man over women'.

132 International Displacement Monitoring Centre, Internally Displaced Women: Gender-based Violence, available online at <internal-displacement.org/8025708F004D404D/(httpPages)/ 953DF04611AD1A88802570A10046397B?OpenDocument> (accessed 03 April 2012).

133 Between 2005 and 2010 at least 321 foreigners travelled to Colombia for organ transplants, and many of the surgeries are 'driven by profit for hospitals, doctors and brokers'. See Edmonton Journal (Alberta), Smith, M., Turning Life into Death, 19 June 2011, available online at $<$ www2.canada.com/edmontonjournal/news/sundayreader/story.html?id=d847ec7f-6115-4032bb1f-166303c93b60> (accessed 18 August 2013), noting: 'In the illegal organ trade, brokers scour the world's slums, preying on the poor with promises of easy money and little risk in exchange for a kidney. Inside hospitals, people are injured or killed by botched surgery as doctors place money above ethics, criminal investigators say.'

134 Supra nt. 93, noting that Colombia is one of the top five "hot spots" in the world for organ trafficking, due to its proximity to medical tourists from the United States seeking cheap operations and Web sites that offer liver and kidney transplants within 90 days.

135 Pittsburg Tribune-Review, Fabregas, L., Transplant 'Tourism' Questioned at Medical Centers in Colombia, 18 February 2007, available online at <highbeam.com/doc/1P2-11273372.html> (accessed 18 August 2013).

136 Debate, Author Unknown, Should the Sale of Organs Be Legal?, available online at $<$ debate.org/opinions/should-the-sale-of-human-organs-be-legal> (accessed 14 June 2013). 
transplants sooner than they can obtain them in their home countries. ${ }^{137}$ This is in direct conflict with the World Health Organization's 1991 Guiding Principles on Human Cell, Tissue and Organ Transplantation, ${ }^{138}$ which state, among other points, that, 1) organs should preferably be obtained from the deceased; 2) living donors should generally be genetically related to recipients; and 3) no payment should be given or received. ${ }^{139}$

Colombia, along with Spain, called for a revision of the World Health Organization's 1991 Guiding Principles on Human Cell, Tissue and Organ Transplantation back in $2003^{140}$ to address the growing problem of "for profit activity". ${ }^{141}$ But a subsequent review by the WHO and International Society of Nephrology (ISN) indicated that transplant commercialisation and human organ trafficking were "rampant" in several countries, including Colombia. ${ }^{142}$ In 2004 , Colombia adopted the language of the WHO Guidelines by enacting Law 919 of $2004^{143}$, mandating that organs cannot be sold commercially and criminalising human organ trafficking. Additionally, Decree 2493 of 2004 provided that foreign visitors could only receive transplants if no Colombian citizens or foreign residents were on a waiting list. ${ }^{144}$ Despite enactment of these laws, Colombia remained one of several hotspots for illegal organ trafficking, ${ }^{145}$ and at one point in the last decade, allegations arose that of 873 transplant operations done in 2007, 69 transplants were done on foreigners and that some of the transplants involved organs taken from deceased persons through commercially arranged transactions. ${ }^{146}$ There are also credible rumours from interviews with doctors in 2013 that organ trafficking is a big business in

137 Colombia is one of the key Latin American nations (along with Argentina, Brazil, Mexico and Peru) in the sale of body parts. See Fox News Latino, O'Reilly, A., "Organ Trafficking on the Rise", 16 August 2012, available online at <latino.foxnews.com/latino/news/2012/08/16/organ-traffickingon-rise-in-united-states/> (accessed 18 August 2013).

138 WHA Resolution 44.25, 13 May 1991.

139 World Health Organisation, REPORT, Report of the World Health Organisation: Ethics, Access and Safety in Tissue and Organ Transplantation: Issues of Global Concern, 2003, available online at <who.int/transplantation/en/Madrid_Report.pdf > (accessed 24 June 2013), 9. The principles were reaffirmed by the sixty-third World Health Assembly in May 2010, in Resolution WHA63.22.

${ }^{140}$ WHO Resolution WHA57.18, 22 May 2004, available online at <apps.who.int/gb/ebwha/pdf_filesAVHA57/A57_R18-en.pdf> (accessed 14 June 2013).

141 US Committee of Foreign Affairs, Organ Harvesting of Religious and Political Dissidents by the Chinese Communist Party: Joint Hearing before the Subcommittee on Oversight and Investigations and the Subcommittee on Africa, Global Health, and Human Rights of the Committee On Foreign Affairs, House of Representatives: $112^{\text {th }}$ Congress, Second Edition, Ser. No. 112-180, 12 September 2012, 18. (statement of Gabriel Danovich, M.D., professor of medicine, UCLA Medical School), available online at <gpo.gov/fdsys/pkg/CHRG-112hhrg75859/pdf/CHRG-112hhrg75859.pdf> (accessed 18 August 2013).

142 Idem, 19.

143 Ley 919 de 2004, Diario Oficial 45771 of 23 December 2004.

144 Decreto 2493 de 2004, Diario Oficial 45631 of 5 August 2004, Art. 40.

145 Reuters, FACTBOX-Five Organ Trafficking Hotspots, 6 August 2007, available online at <reuters.com/article/2007/08/05/idUSL01426288> (accessed 18 August 2013).

146 Shimazono, Y., "The State of the International Organ Trade: A Provisional Picture Based on Integration of Available Information", Bulletin of the WHO, vol. 85, ed. 12, 2007, 901-980, citing Pittsburg Tribunal Review, Fabregas, L., Transplant 'Tourism' Questioned at Medical Centers in Colombia, 18 February 2007, available online at <highbeam.com/doc/1P2-11273372.html> (accessed 18 August 2013). 
Colombia, particularly in cities where there are good medical centres and a large population of displaced persons. ${ }^{147}$

\section{III.3. Trafficking of Colombians Abroad}

Of the estimated 70,000 Colombian women and children who fall prey to human trafficking each year, ${ }^{148}$ many enter one of about 560 trafficking pipelines within Colombia, ${ }^{149}$ and about 254 of trafficking pipelines out of Colombia into Ecuador and Venezuela, and into Europe (Spain, Germany and Holland), Asia (China, Japan, and Singapore), North America and Central America, and the Middle East (particularly Jordan and Iran). ${ }^{150}$ Many victims are lured by employment and education opportunities, and dating and marriage services. Traffickers place newspaper and Internet ads with catch phrases like, "To Spain with work and papers," "International modelling agency needs young women/men to work in Europe," "Women needed to babysit children in Holland," or "Scholarships to study in the United States." 151 Sadly, it is believed that three out every ten Colombian females between the ages of 14 and 21 years who enter the fashion world will become victims of human trafficking. ${ }^{152}$ Older women in their thirties are also vulnerable to being trafficked into servitude as maids and nannies. ${ }^{153}$ Traffickers also target small villages and convince parents that their children will be better off with "a friend of the family," a tactic that is used by traffickers worldwide. ${ }^{154}$ It should be noted, however, that children are also brought

${ }^{147}$ Interviewed by the author: The doctors do not want to be identified for their own safety because they assert that important government officials are directly profiting from organ trafficking and that international organised crime is also deeply involved.

148 Inter Press service, Martinez, H., Rights-Colombia: Endless Pain Awaits Victims of Sex Trade, 11 June 2009, available online at <business.highbeam.com/409433/article-1G1201668762/rightscolombia-endless-pain-awaits-victims-sex-trade> (accessed 09 September 2013). See also The Protection Project, A Human Rights Report on Trafficking in Persons, Especially Women and Children, September 2010, Colombia Country Report at The Johns Hopkins University School of Advanced International Studies, available online at <protectionproject.org/wpcontent/uploads/2010/09/Colombia.pdf $>$ (accessed 13 June 2013), noting that Colombia has the third-highest number of trafficking victims in Latin America, following the Dominican Republic and Brazil.

149 "Colombia is a major source country for women and girls subjected to sex trafficking in Latin America, the Caribbean, Western Europe, Asia, and North America, including the United States, as well as a transit and destination country for men, women, and children subjected to forced labor.", U.S. Dpt. of State, Trafficking in Persons Report, 2011, 205, available online at <state.gov/j/tip/rls/tiprpt/2011/index.htm> (accessed 26 June 2013).

150 El Tiempo, Redacción Justicia, 560 rutas de tráfico de mujeres y niñas en el país tienen redes de trata de personas, 31 March 2009, available online at <eltiempo.com/archivo/documento/CMS4930107> (accessed 09 September 2013).

151 Toro Bedoya, J.A., "Reflexiones sobre la Trata de Personas Fenomeno que Afecta el Desarrollo Humano de los Colombianos", Revista Eleuthera, vol. 3, December 2009, 190-191.

152 EFE Newswires, ONU acompanara a modelos en caigan en trata de personas, 3 March 2010, available online at <vanguardia.com/historico/55090-onu-acompanara-a-modelos-en-concursopara-que-no-caigan-en-trata-de-personas $>$ (accessed 09 September 2013).

153 Martinez, H., 2009, supra, nt. 156. In one case, a woman named Mara, a 40 year-old unemployed mother from Tolima, was offered a job as a domestic worker for an affluent Colombian family in the United States. Upon her arrival, Mara was put to work 19 hours a day, with barely any food to sustain her. Her weight dropped from 58 kilograms to 41 kilograms in just 39 days. After she attempted to report her exploitative situation to the police, her abusers threatened her family in Colombia. Mara was finally able to escape thanks to the help of a neighbor that realised the exploitation to which Mara was subjected.

154 Toro Bedoya, J.A., 2009, supra, nt. 159 
into Colombia from other countries to supply the demand of sex tourists coming to Colombia from the United States, Europe, and other South American countries. ${ }^{155}$

The Colombian conflict has caused a spill-over of refugees into neighbouring states. Many refugee families flee Colombia out of fear that their children will be recruited into illegal armed groups, or worse, that they or other family members will be maimed or killed by the fighting. A majority of women, or approximately 44 percent of the estimated 135,000 refugees that have crossed the Colombian border, end up in the region bordering northern Ecuador, the main recipient state for Colombian refugees. ${ }^{156}$ Most Colombian refugees and asylum seekers travel to Lago Agrio, in the province of Sucumbíos, where they become easy prey for labour and sex traffickers. Sucumbíos is a difficult place. Widespread poverty, the presence of illegal armed groups, organised criminal networks, ${ }^{157}$ and many male oil workers and members of the military ${ }^{158}$ create conditions conducive for the trafficking of Ecuadorian women and female Colombian refugees into labour servitude and forced prostitution. ${ }^{159}$ Although information on human trafficking per se is not readily available, it is estimated that about 70 percent of female registered "sex workers" in the region of Sucumbíos are Colombian and of these, some 50 percent are minors. ${ }^{160}$ As members of the Organization of American States, this exploitation places both Colombia and Ecuador in direct violation of the Inter-American Convention on International Traffic in Minors, ${ }^{161}$ which among its many measures, calls for ensuring "the protection of minors in consideration of their best interests" 162 and for the "prompt return of minors who are victims of international trafficking to the State of their habitual residence, bearing in mind the best interests of the minors." 163 In addition, victims, mostly

155 Council on Hemispheric Affairs, Vasquez, J. and Bacon, K., "Colombia and Peru Facing Mountainous Path to Eradicating Slavery", Washington Report on the Hemisphere, vol. 32, ed. 19 \& 20, 16 November 2012, 10, available online at <coha.org/wp-content/uploads/2012/11/WRH-32.19and-20.pdf $>$ (accessed 09 September 2013).

156 U.S. Dpt. of State, Trafficking in Persons Report 2011, 148, available online at <state.gov/j/tip/rls/tiprpt/2011/index.htm> (accessed 26 June 2013), noting: "Ecuador is a destination country for Colombian, Peruvian, and to a lesser extent, Chinese women and girls subjected to sex trafficking. Indigenous Ecuadorians are vulnerable to forced labor in domestic service. Colombian refugees and migrants are subjected to forced labor in palm oil plantations." See also Velez, A.C.A., Gender-Based Violence towards Colombian Uprooted Women in the Northern Borderland of Ecuador, dissertation, Geneva, 2009, 27-28, available online at <graduateinstitute.ch/webdav/site/genre/shared/Genre_docs/2342_TRavauxEtRecherches/Mem oire_AndreettiVelez.pdf> (accessed 14 June 2013).

157 Semana, Cocaína decomisada en Ecuador pertenece a las FARC, 13 October 2009, available online at <semana.com/mundo/articulo/cocaina-decomisada-ecuador-pertenece-farc/108617-3> (accessed 09 September 2013).

158 Velez, A.C.A., supra, nt. 164, 27-28.

159 The International Organization for Migration (IOM) has signed a series of agreements with the authorities of the Ecuadorian provinces of Sucumbios and Esmeraldas in order to strengthen local capacity to combat human trafficking, mainly in the northern border cities of Lago Agrio and San Lorenzo. See Int'1 Office on Migration, La IOM Signs Two New Agreements to Strengthen the Fight Against Human Trafficking in Ecuador, 17 June 2011, available online at <iom.int/cms/en/sites/iom/home/news-and-views/press-briefing-notes/pbn-2011/pbnlisting/iom-signs-two-new-agreements-to-strength.html> (accessed 09 September 2013).

160 Velez, A.C.A., supra, nt. 164, 36-37.

161 Inter-American Convention on International Traffic in Minors, (hereafter referred as O.A.S.T.S.) No. 79, official Web site of the Organization of American States, <oas.org/juridico/english/treaties/b-57.html> (accessed 28 June 2013). Colombia ratified the Convention on 12 June 2000, and Ecuador ratified on 20 May 2002.

162 O.A.S.T.S., art. 1(a)

163 O.A.S.T.S., art. 1(c) 
between the ages of 14 and 22 years, are sold as 'brides' ${ }^{164}$ to individuals who will then sexually exploit them and/or resell them to another trafficker. This constitutes a clear violation of the Optional Protocol to the Convention on the Rights of the Child on the Sale of Children, ${ }^{165}$ which requires punishment for those "offering or delivering children for the purposes of sexual exploitation, transfer of organs or children for profit or forced labour," which could be either or both Colombian and Ecuadorean actors, as well as punishment "for anyone accepting the child for these activities."166 Coincidentally, Sucumbíos encompasses most of the 30 crossing points for weapons smuggling, drug trafficking and human trafficking, and establishes the link between the products trafficked and the routes used to transport different types of illicit goods and trafficking victims.

Women also become victims of sexual exploitation by border patrol and immigration police officers who take advantage of their vulnerable situation. The officials force the refugee women to have sexual relations or face deportation, and police officers are also known to detain women in jail for several days where it is generally assumed that the women may be abused. ${ }^{167}$ Tragically, despite the abuse to which they are subjected by different groups, women do not see themselves as victims of human rights violations, but rather interpret their situation as a temporary means of survival. ${ }^{168}$ Such an attitude only empowers the abusers.

Among the estimated 100,000 Latin Americans trafficked internationally each year, a large number of Colombians are sent to Japan for sexual exploitation, ${ }^{169}$ which during the last decade was very slow to address human trafficking as a problem there. ${ }^{170}$ In what is considered a laissez-faire attitude toward the sex trade, prostitution is referred to as "compensated dating." 171 Even married Japanese women are complacent, accepting that their husbands may engage in prostitution as long as they do not leave their wives for foreign women. In fact, Japanese women have the attitude that these foreign women are not even "human beings like them," 172 an attitude that makes it quite difficult to change societal perceptions of the problem.

\section{Colombia's Obligations to Protect Its Citizens}

\section{IV.1. Legal Framework and Meeting International Obligations}

164 Velez, A.C.A., supra, nt. 164, 37.

165 Optional Protocol to the Convention on the Rights of the Child on the Sale of Children, Child Prostitution and Child Pornography, G.A. Resolution 54/263, Annex II, A/RES/54/263, March 16, 2001, available online at <unicef.org/crc/index_30204.html>. Colombia ratified this on November 11, 2003 and Ecuador ratified on January 30, 2004.

166 See explanation of the Optional Protocol on the Sale of Children, Child Prostitution and Child Pornography on the UNICEF webpage, available at <unicef.org/crc/index_30204.html> (accessed June 27, 2012).

167 Velez, A.C.A., supra, nt. 164, 39-40.

168 Ibid.

169 Seelke, C.R., REPORT, Trafficking in persons in Latin America and the Caribbean, Congressional Research Service Report for Congress, July 15 2013, available online at $<$ fas.org/sgp/crs/row/RL33200.pdf> (accessed 09 September 2013).

170 BBC, Monitoring International, Japanese Police Uncovers 83 Cases of Foreign Sex Slaves in 2003, 25 March 2004, available online at <accessmylibrary.com/coms2/summary_0286-20805640_ITM> (accessed 09 September 2013).

171 Ibid.

172 BBC, Monitoring International, Japanese Police Uncovers 83 Cases of Foreign Sex Slaves in 2003, BBC Monitoring Int'1 Rep. (March 25, 2004), quoting Yoko Yoshida, a lawyer for the Japan Network Against Human Trafficking in Persons (not available online). 
Colombia's internal conflict presents a challenge for the government. In order to confront illegal groups and effectively achieve peace and security for all citizens and ensure their full enjoyment of their rights, the GOC needs to apply effectively all provisions of both international human rights and economic, civil and cultural rights treaties. Such implementation needs to be part of the State's policy. This situation poses an unequivocal challenge for the Colombian State and requires the provision of both human and economic resources for effectively confronting these illegal groups ${ }^{173}$ and fighting human trafficking, with a view to achieving peace and giving all citizens' full enjoyment of their rights. As evidence of the GOC's commitment to human rights, 55 percent of the resources allocated to between 2002 and 2006 were dedicated to creating conditions of peace and generating development in depressed areas and among victims of violence; on the protection and promotion of human rights and international humanitarian law; on reforming the criminal justice system; and on strengthening the executing agencies pursuing those objectives.

Colombia has plenty of laws and the Constitutional Court has done a yeoman's job of interpreting the laws. Overall, Colombia's legal framework is comprehensive. Its domestic legislation and jurisprudence prohibits human rights abuses and international crimes, including human trafficking. It incorporates international obligations into domestic legislation and promulgates legislation for the rights of the victims. ${ }^{174}$ It implements policies addressing the rights and needs of displaced people. Where the State falls short is in the lack of coherence between law and policies such that the State has failed to address stigmatisation and discrimination of displaced people, and has not alleviated their suffering nor created a safer and secure environment for them wherein they may exercise their rights. Even though the Colombian legal framework "takes into account the unique needs of displaced women and girls, and assigns government actors specific obligations to prevent gender-based violence against displaced women," poor follow-through of the laws prevents displaced people, especially women and children, from overcoming barriers to seeking justice and needed social services. ${ }^{175}$

As a party to many international conventions, the GOC has a duty to abide by its commitments to extend the protections afforded under international law and international humanitarian law to all citizens. International human rights treaties and international humanitarian norms duly ratified by Colombia become part of its Constitution under the doctrine of "Constitutional Block." 176 Under the Constitutional

173 United Nations Committee on the Elimination of Racial Discrimination, Reports Submitted by States Parties in Accordance with Article 9 of the Convention, Fourteenth Periodic Report: State Parties Due in 2008, Addendum: Colombia 7 Sec. F: Armed Violence, para. 33, 29 February 2008, International Convention on the Elimination of All Forms of Racial Discrimination, CERD/C/COL/14 (on file with the author).

174 Ley 1257 de 2008, Diario Oficial, No. 47.193, 4 December 2008, available online at <www.secretariasenado.gov.co/senado/basedoc/ley/2008/ley_1257_2008.html> (accessed 3 July 2012).

175 Human Rights Watch, Rights Out of Reach. Obstacles to Health, Justice, and Protection for Displaced, Victims of Gender-Based Violence in Colombia 30, 2012, available online at <peacewomen.org/assets/file/colombia1112forupload.pdf> (accessed 23 June 2013).

176 The Constitutional Block doctrine is a recent jurisprudential development that emerged from French law. The Constitutional Court used it for the first time in Sentencia No. C-225/95, when it determined that international humanitarian laws are ius cogens norms of obligatory character for all illegal armed groups and State employees, especially members of the armed forces. The Court also found that international humanitarian law is part of human rights and at the same time, complement each other; both "are ius cogens norms that above all, seek to protect the dignity of human persons," the Court wrote. 
Block doctrine, several principles, treaties and rules may form part of the Colombian Constitution notwithstanding them being explicitly mentioned in the charter. Those treaties have constitutional rank and primacy in domestic law, and no national law or provision may conflict with them.

The Constitutional Block has expanded over the years ${ }^{177}$ to include international human rights treaties, ${ }^{178}$ humanitarian law, treaties ratified by Colombia that

The Court then had to determine how to harmonise two apparently contradictory constitutional articles: art. 4, which establishes the supremacy of the Constitution over treaties; and art. 93, which gives priority and supremacy in the domestic order to some contents of human rights treaties. Using the Constitutional Block doctrine, the Court decided that under art. 93 of the Colombian Constitution, international humanitarian law norms have constitutional rank and therefore prevalence and supremacy in the internal order.

The Court then needed to decide what hierarchical position those norms occupied in the Colombian Constitution, and determined that "human rights treaties and international humanitarian law treaties form a "constitutional block" with the rest of the Constitution. In this manner the principle of constitutional supremacy as a norm of norms is harmonised, with prevalence of treaties ratified by Colombia, which recognised human rights and those rights are of the kind that cannot be suspended during state emergency." See Sentencia No. C-225/95, available online at $<$ corteconstitucional.gov.co/relatoria/1995/c-225-95.htm> (accessed 12 June 2013). The Court has since used this doctrine in criminal matters related to obedience of the military, in Sentencia No. C225/95 and Sentencia No. C-578/95, respectively, and the rights of the victims of crime, in Sentencia No. C-282/02, Sentencia No. C-04/03 and Sentencia No. T-249/03. See Uprimny , R, Bloque de constitucionalidad, derechos humanos y nuevo procedimiento penal, unpublished paper for the American University Human Rights Academy, available online at $<$ wcl.american.edu/humright/hracademy/documents/Clase1-

Lectura3BloquedeConstitucionalidad.pdf $>$ (accessed 3 July 2013).

177 Precedente, Olaya, M.A., El bloque de constitucionalidad en la jurisprudencia de la Corte Constitucional colombiana, 2004, vol. 80, 86-94, available online at $<$ bibliotecadigital.icesi.edu.co/biblioteca_digital/bitstream/item/949/1/Bloque_constitucionalidad. pdf $>$ (accessed 3 July 2013).

178 Colombia has "signed and ratified most of the international covenants, protocols and conventions related to human rights." These include:

Regional:

- Acceptance of the competence of the Inter-American Court of Human Rights, June 21, 1985

- American Convention on Human Rights, Nov. 22, 1969, 1144 U.N.T.S. 123, 9 I.L.M. 673, ratified Jan. 28, 1973

- Inter-Am. Convention on the Prevention, Punishment, and Eradication of Violence Against Women, June 9, 1994, 33 I.L.M. 1534, ratified Oct. 3, 1996

- Additional Protocol to the American Convention on Human Rights in the Area of Economic, Social and Cultural Rights (Protocol of San Salvador), Nov. 16, 1999, O.A.S.T.S. No. 69, 28 I.L.M. 1641, ratified Oct. 22, 1997

- Inter-American Convention to Prevent and Punish Torture, Dec. 9, 1985, O.A.S.T.S. No. 67, ratified Dec. 2, 1998

International:

- 1949 Geneva Conventions (ratified 1961), Additional Protocol I of 1977 (ratified 1993), and Additional Protocol II (ratified 1995);

- International Covenant on Economic, Social and Cultural Rights, G.A. Res. 2200 (XXI) A, U.N. Doc. A/RES/2200(XXI) (Dec. 16, 1966), ratified Oct. 29, 1969;

- International Covenant on Civil and Political Rights, G.A. Res. 2200 (XXI) C, U.N. Doc. A/RES/2200(XXI) (Dec. 16, 1966), ratified Oct. 29, 1969;

- First Optional Protocol to the International Covenant on Civil and Political Rights, ratified Oct. 29, 1969

- Convention on the Elimination of All Forms of Discrimination against Women (CEDAW), G.A. Res. 34/180, UN GAOR, 34th Sess., Supp. No. 46, at 193, U.N. Doc. A/34/46, 1249 UNTS 13, ratified Jan. 19, 1982;

- Optional Protocol to the Convention on the Elimination of All Forms of Discrimination against Women (CEDAW-OP), December 10, 1999, 2131 UNTS 83, ratified Jan. 23, 2007; 
recognised intangible rights, and jurisprudence developed by international tribunals in relation to those international standards. ${ }^{179}$

Two conditions must be fulfilled before international human rights treaties may be incorporated into the Colombian Constitution: Treaties must have been ratified by Colombia, and those rights cannot be suspended during a state of emergency. ${ }^{180}$ All rights and duties enshrined in the Constitution must be interpreted in conformity with the provisions of those international human rights treaties. ${ }^{181}$ According the

- Declaration on the Protection of Women and Children in Emergency and Armed Conflict, G.A. res. 3318 (XXIX), 29 U.N. GAOR Supp. (No. 31) at 146, U.N. Doc. A/9631 (1974), ratified Dec. 14,1974

- Declaration on the Elimination of Violence against Women. U.N. Doc. A/48/49 (1993), ratified Dec. 20, 1993;

- Convention on the Rights of the Child (CRC), U.N. Doc. A/48/49 (1993), ratified Jan. 28, 1991;

- Optional Protocol to the Convention on the Rights of the Child on the Sale of Children, Child Prostitution and Child Pornography (CRC-OPSC), G.A. Res., 54/263, Annex II, A/RES/54/263, (March 16, 2001), ratified Nov. 11, 2003;

- Optional Protocol to the Convention on the Rights of the Child on the Involvement of Children in Armed Conflict (CRC-OPAC), G.A. Res. 54/263, Doc. A/54/49 (May 25, 2000), ratified May 25, 2005;

- ILO Convention concerning Minimum Wage for Admission to Employment, art. 3, June 26, 1973, 1015 UNTS 297 (1973), ratified Feb. 2, 2001;

- Convention concerning the Prohibition and Immediate Action for the Elimination of the Worst Forms of Child Labour, art. 3(a), June 17, 1999, 38 I.L.M. 1207, ratified Jan. 28, 2005;

- Abolition of Forced Labor Convention, 1957 (No. 105), June 25, 1957, 320 U.N.T.S. 291, ratified June 7, 1963;

- Protocol to Prevent, Suppress, and Punish Trafficking in Persons Especially Women and Children supplements the Convention Against Transnational Organized Crime (CATOC), supplementing the United Nations Convention against Transnational Organized Crime, G.A. Res. 55/25, A/RES/55/25 (Nov. 15, 2000) (Colombia has ratified but date is unknown)

- Convention for the Protection of Cultural Property in the Event of Armed Conflict, May 14, 1954, 249 UNTS 240, ratified June 18, 1998;

Curiously, Colombia has NOT signed or ratified the following important international conventions:

- Slavery Convention, Protocol amending the Slavery Convention signed at Geneva on 25 September 1926, Sept. 25, 1926, 212 U.N.T.S. 17;

- Supplementary Convention on the Abolition of Slavery, the Slave Trade, and Institutions and Practices Similar to Slavery, Forced Labour Convention, 1930 (No. 29), Sept. 27, 1956, 266 UNTS 3;

- Convention for the Suppression of the Traffic in Persons and of the Exploitation of the Prostitution of Others, G.A. Res. 317 (IV), U.N. Doc. A/RES/317(IV) (Dec. 2, 1949)

179 Court jurisprudence has redefined the block in sources and content. The following are now part of the Constitutional Block: in stricto sensu: (i) the Preamble, (ii) constitutional norms, (iii) boundary treaties ratified by Colombia, (iv) humanitarian law treaties, (v) treaties that recognised intangible rights ratified by Colombia, (vi) articles of human rights treaties ratified by Colombia, when they deal with rights recognised by the Constitution, and (vi), at least as a relevant criterion of interpretation, to some extent, doctrine developed by international tribunals in relation to those international standards. Uprimny, R., supra, nt. 184, noting: "Obviously, this generic list specifically includes ILO conventions and the doctrine drawn up by the supervisory bodies of the international organization. And on the other hand, to integrate the block in latu sensu, one would need to add to the previous guidelines (i) statutory laws and (ii) organic laws, the relevant, with the proviso that some court rulings exclude some statutory laws of their integration to the constitutional block in latu sensu."

180 Art. 93 C.C.: "International treaties and agreements ratified by the Congress, which recognize human rights and which prohibit their limitation in exceptional circumstances, take prevalence in internal order. The rights and responsibilities consecrated in this charter will be interpreted in conformity with international human rights treaties ratified by Colombia."

${ }^{181}$ Sentencia No. C-358/1997 (determining that those rights become part of a "constitutional block). 
Constitutional Court, International humanitarian law is also part of the "constitutional block." 182 Moreover, innominate rights are also included in the Constitution. "The declaration of rights and guarantees contained in the Constitution and in international agreements in force, should not be understood as a denial of others rights inherent to the human person which are not expressly referred to in them." 183

In sum, four provisions play a crucial role in the Constitutional Block:

1. Article 53, establishes that once ratified, international labour conventions become part of the domestic law.

2. Article 93, establishes that certain international standards of human rights "prevailing in the internal order" and "the rights and duties enshrined in this Charter shall be interpreted in accordance with the international treaties on human rights ratified by Colombia."

3. Article 94, incorporates the unnamed rights clause and states that "the enunciation of rights and guarantees contained in the Constitution and the international agreements in force should not be understood as a denial of others which, being inherent in the human person, are not expressly referred to in them.

4. Article 214, which regulates states of emergency, indicates that even in times of crisis, human rights and fundamental freedoms cannot be suspended and that "in all cases the rules of international humanitarian law will be respected." 184

Therefore, the following treaties duly ratified by Colombia, international human rights instruments, and customary law form part of the constitutional legal regulations under the Constitutional Block doctrine:

1977 Additional Protocol II

a. Article 4(2) of the 1977 , on rape and sexual violence ${ }^{185}$

b. Article 4(2)(f), on slavery and slave trade ${ }^{186}$

Customary International Law

182 Sentencia No. C-225/1995 decided the constitutionality of Law 171 of 1994, which approved Protocol II Additional to the Geneva Conventions of 1949.

183 Art. 94 C.C..

184 Uprimny, R., supra, nt. 184.

185 In Sentencia No. C-291/07, the Constitutional Court held that taking into account the development of customary international humanitarian law applicable in internal armed conflicts, fundamental guarantees stemming from the principle of humanity, some of which have attained ius cogens status, include the prohibition of gender violence, sexual violence, enforced prostitution and indecent assault. In addition, art. 139 and art. 141 of Colombia's Penal Code (2000) imposes a criminal sanction on anyone who, during an armed conflict, carries out or orders the "carrying out of forced sexual acts on protected persons" and "forced prostitution or sexual slavery.", available online at <icrc.org/customary-ihl/eng/docs/v2_cou_co_rule93> (accessed 1 July 2013).

186 Also in Sentencia No. C-291/07, the Constitutional Court stated that the essential principles of international humanitarian law have acquired ius cogens status, based on the fact that the international community as a whole has recognised their peremptory and imperative nature in the same way it has recognised this for other cardinal provisions such as ... the prohibition of slavery. Art. 17 of the Colombian Constitution prohibits slavery or any form of forced labour, available online at <confinder.richmond.edu/admin/docs/colombia_const2.pdf> (accessed 3 July 2013). 
1. Forced labour. The Constitutional Court, considering the "development of customary international humanitarian law applicable in internal armed conflicts, notes that fundamental guarantees stemming from the principle of humanity, some of which have attained ius cogens status ... [include] the prohibition of uncompensated or abusive forced labor. ${ }^{187}$

2. Respect for Family life. In Constitutional Court Case No. C-291/07, the Plenary Chamber of Colombia's Constitutional Court stated:

--Taking into account ... the development of customary international humanitarian law applicable in internal armed conflicts, the Constitutional Court notes that the fundamental guarantees stemming from the principle of humanity, some of which have attained ius cogens status, ... [include] the obligation to respect family life ${ }^{188}$

3. Forced Displacement.

a. In 2004, the Constitutional Court found that Colombia's response to internal displacement constituted an "unconstitutional state of affairs" and recognised that certain minimum rights of the internally displaced population exist that must be satisfied by the authorities to ensure a life with dignity. The minimum protection which must be timely and effectively guaranteed implies (i) that in no case may the essential core of constitutionally guaranteed fundamental rights of displaced persons be threaten and (ii) the satisfaction of, at a minimum, the rights to life; to dignity; to physical, psychological and moral integrity; to the family unit; the provision of basic and/or urgently needed health services; protection from discrimination on the basis of displacement; and the right to education up to fifteen years in the case of displaced children. According to the Court, the national and territorial authorities must adopt and implement measures to correct and reverse situations where any of these minimum protections have not been realised. The Court stated that one of the problems in the design and execution of "State policy regarding comprehensive care of the displaced population is the lack of a specific approach to these population groups that would make it possible to identify and address their particular and pressing needs deriving from their specific situation within that of internal displacement." 189

b. In its third periodic report to the Committee on the Rights of the Child, Colombia acknowledged that the problem of people displaced

187 The Constitutional Court, in Sentencia No. C-291/07, noted that art. 150 of the Colombian Penal Code (2000) imposes a criminal sanction on anyone who, during an armed conflict, compels or orders the compelling of a protected person to serve in the armed forces of the enemy.

188 According to art. 2(4) of Colombia's Law on Internally Displaced Persons (1997), the family of forcibly displaced persons must benefit from the right to family reunification. This right is also addressed by the Constitutional Court in Sentencia No. C-291/07.

189 According to the Constitutional Court in Sentencia T-025/2004, social spending on marginalised populations is regarded as priority expenditure. There is a State policy of attention to the displaced population, articulated in a law of the Nation, a detailed regulatory framework, and a quantification of the budget effort required to comply with constitutional and legal mandates. However, the authorities responsible for ensuring the adequacy of these resources have omitted repeatedly to adopt the remedies needed to ensure that the level of protection defined by the Legislature and developed by the Executive, is effectively achieved. 
by the violence worsened as a result of paramilitary and guerrilla activity, but also, as a result of State forces clashing with these illegal groups. This phenomenon is one of the most serious human rights violations. ${ }^{190}$

c. In 2005, analysing the constitutionality of the 1977 Additional Protocol II, the Constitutional Court found that "in relation to the rules on the protection of civilians and persons hors de combat: . . . more than half a million Colombians have been displaced from their homes as a result of the violence. ... The principal cause of displacement involves violations of international humanitarian law associated with the armed conflict." 191

Protection of women and children is addressed by several articles of the Geneva Conventions. Among the articles are the duty of state parties to treat women with due consideration on the basis of their sex, ${ }^{192}$ and the duty to protect women against rape, enforced prostitution, and other forms of indecent assault. ${ }^{193}$ Colombia must also meet its obligations under Additional Protocol II to ensure that in its internal armed conflict, all persons, including women and children, who do not, or who have ceased, taking direct part in hostilities, are entitled to respect for their person and honour and must be treated humanely. ${ }^{194}$ Under the Rome Statutes, which apply to both international and internal armed conflicts, Colombia has a duty to prosecute as war criminals actors involved in outrageous acts of sexual violence and particularly humiliating and degrading treatment. ${ }^{195}$

The observations of the United National High Commission on Human Rights, presented in April 2013, read like a laundry list of issues that have not been addressed sufficiently by the GOC. These include conforming to basic international human rights requirements such as gathering accurate data on human trafficking of children. For example, in 2011 the GOC reported only 483 instances of children being coerced into sex and forced labour and into the drug trade by illegal armed groups, a number that would suggest to any reasonable person an alarming level of under-reporting. ${ }^{196} \mathrm{In}$ fact, the international community has taken the GOC to task for careless reporting and for failing to identify and investigate trafficking victims "due to the lack of effort and resources in inspecting the informal and illicit sectors of the market." 197

The GOC is obliged to conform to international norms regarding human rights, including recognising that sexual violence, associated with all forms of human trafficking, is a crime under international law, and specifically under the Protocol to Prevent, Suppress, and Punish Trafficking in Persons Especially Women and Children, ${ }^{198}$ as well as under the Rome Statute of the International Criminal Court,

190 International Committee for the Red Cross, Colombia: Practice Relating to Rule 129, The Act of Displacement, available online at <icrc.org/customary-ihl/eng/docs/v2_cou_co_rule129> (accessed 1 July 2013).

191 Sentencia No. C-225/95, revising Additional Protocol II and its implementing law, Law 171 of 1994 (Ley 171 de 1994, Diario Oficial, No. 41.640, 20 December 1994).

192 Geneva Convention I, art. 12(4), and Geneva Convention II, art. 12(4).

193 Geneva Convention IV, art. 27, and Additional Protocol I, art. 76.

194 Additional Protocol II, art. 4(1).

195 ICC Statute, arts. 8(2)(b)(xxi); (xxii); 8(2)(c)(ii); 8(2)(e)(vi).

196 Vasquez, J., \& Bacon, K., 2012, supra, nt. 163

197 Ibid.

198 The Protocol to Prevent, Suppress, and Punish Trafficking in Persons Especially Women and Children supplements the Convention Against Transnational Organized Crime (CATOC), G.A. Resolution 55/25, A/RES/55/25 (Nov. 15, 2000), and the U.N. Convention Against Transnational 
which could become a venue for the prosecution of human rights abusers, should the Colombian government prove unwilling or unable to do so. ${ }^{199}$ The state of internal conflict in Colombia compelled the international community to make several recommendations to the GOC through a dialogue between Colombia and 76 member states., issued through the UNHCR on April 23, 2013 ${ }^{200}$ The pertinent recommendations include:

- To reinforce efforts to end impunity for human rights violations;

- To develop at the regional level State institutions tasked with preserving historic memory with of the armed conflict;

- To strengthen measures to rehabilitate child victims of the armed conflict and to investigate all cases of illegal recruitment of children into armed groups;

- To increase efforts to address violence against women, including access to justice, medical care for victims, social reintegration and combatting impunity for such acts;

- To step up efforts to combat human trafficking vis-à-vis the new National Strategy to Combat Trafficking in Persons 2013-2018;

- To ensure appropriate protection of human rights defenders operating in the country and to increase efforts to investigate and prosecute those responsible for threats or violence against human rights defenders;

- To introduce stronger measures to protect indigenous peoples and Afro-Colombians from attacks by armed groups; to implement the law on Victims and Land Restitution in a just manner;

- To intensify efforts aimed at providing access to free and compulsory primary education to all children;

- Ratification of human rights instruments.

These calls for action fall on the heels of the UNHCR's January 2013 report on Colombia which urged the GOC to take immediate and decisive action to shore up efforts undertaken to address grave human rights concerns, among them displacement, violence against women and children, and human trafficking.

The GOC is also a party to several international instruments concerned with assisting the victims of internal armed conflict and suppressing human trafficking. For example, Colombia is obliged by the UN Security Council's Resolution 1325 of October 31, 2000201 addressing the UN's concern that women and children are particularly targeted for exploitation and abuse, to respect the rights and protection of

Organized Crime and the Protocols Thereto, Annex I, art. 2(a), Nov. 15, 2000, 2225 U.N.T.S. 209. Colombia has been a party to both since ratifying them on August 4, 2004.

199 Rome Statute of the International Criminal Court, 1998, 2187 UNTS, art. 1, 90 available online at $<$ treaties.un.org/doc/publication/UNTS/Volume\%202187/v2187.pdf>. See also Wallström, M., "2012 Special Issue: Gender and Post-Conflict Transitional Justice: Introduction: Making the Link between Transitional Justice and Conflict-related Sexual Violence", Wm. \& Mary J. Women \& L., vol. 19, Iss. 1, 2012, 3. Colombia signed the Rome Statute on December 12, 2000 and ratified it on August 5, 2002.

${ }^{200}$ The 76 nations included 28 HRC members and 38 observers; UNHCR, Universal Periodic Review Media Brief, available online at <ohchr.org/EN/HRBodies/UPR/Pages/Highlights23April2013pm.aspx> (accessed 23 April 2013).

${ }^{201}$ SC Resolution 1325/2000, 31 October 2000. 
women and girls during and after conflicts. Despite such obligations, a great number of Colombian women and children, especially those who have been displaced, continue to be subjected to servitude and sexual exploitation and violence, ${ }^{202}$ while their precarious circumstances predispose them to sexual violence. ${ }^{203}$ Displacement exacerbates exploitation and abuse and remains a fundamental cause of human trafficking in Colombia.

To meet international obligations imposed on Colombia by Additional Protocol $\mathrm{II}^{204}$ and bring some form of security to the national territory, in 2011 the GOC under President Santos enacted a series of laws and decrees known collectively as the Victims and Land Restitution Law in an attempt to address the status of some four million Colombians displaced by the internal armed conflict. ${ }^{205}$ The Victims and Land Restitution Law is particularly significant because it recognised the true nature of Colombia's internal armed conflict. This was an important departure from Uribe, who never acknowledged that a state of internal armed conflict existed in Colombia. Rather, Uribe used other "labels" to describe the violence in Colombia. For instance, the GOC was not fighting an internal armed conflict against organised military combatants, but was instead conducting a series of internal government "operations" against illegal armed groups, and when the GOC initiated a democratic security policy plan as part of Plan Colombia following the 9/11 terrorist attacks in the United States, Uribe described what the government was doing as fighting terrorism, not fighting an internal armed conflict. ${ }^{206}$

The principle focus of the Victims and Land Restitution Law was to award damages and to restore millions of hectares of stolen land to rightful owners and to the relatives of individuals killed in the conflict. ${ }^{207}$ It doesn't, however, fully address the economic, social, and cultural rights of the victims because this law is only concerned with land restitution, financial compensation, and land rights which emerged during the conflict. It does not address the root of the problem per se by looking at other related rights. Land ownership is something which falls under the rubric of economic, social and cultural rights - the point being that the law should have been crafted to address economic, social and cultural rights as a whole, and not just as a consequence of the conflict.

202 Céspedes-Báez, Lina María, "Les vamos a dar por donde más les duele. La violencia sexual en contra de las mujeres como estrategia de despojo de tierras en el conflicto armado colombiano", Revista Estudios Socio-Jurídicos, vol. 12, ed. 2, 2010, 273-304.

203 This is a problem that has persisted since at least 2003 when the GOC's Ministry for Social Protection reported that "36 percent of internally displaced women had been forced by men into sexual relations." UN OCHA/IRIN, The Shame of War - Sexual Violence against Women and Girls in Conflict, 2007, available online at <iiav.nl/epublications/2007/shameofwar.pdf $>$ (accessed 24 June 2013). See also Meertens, D., "¿Justicia desigual? cGénero y derechos de las víctimas en Colombia” in: Meertens, D., La tierra, el despojo y la reparación: justicia de género para las mujeres víctimas en Colombia, 2009, Bogotá.

204 Additional Protocol II, art 17. Forced displacement of civilian populations within a country and across a border in non-international armed conflicts is prohibited unless the security of the civilians or imperative military reasons so demand.

205 The legislative and executive acts comprising the Victims and Land Restitution Law are: Ley 1448 de 2011, Diario Oficial 48096 of 10 June 2011; Decreto 4800 de 2011, Diario Oficial 48280 of 20 December 2011; and Decreto 4829 de 2011, Diario Oficial 48280 of 20 December 2011, respectively.

206 The Uribe administration also signed the 1996 International Convention for the Suppression of the Financing of Terrorism on October 20, 2001.

207 According to a country report provided to the UN High Commissioner on Human Rights, more than 150,000 victims received some form of compensation in 2012. See State News Service, Council Discusses Country Reports under Agenda Items on Annual Report of the High Commissioner and on Technical Assistance, 20 March 2013. 
The land restitution plans met with strong resistance from the illegal armed groups responsible for stealing territory, especially paramilitary groups with close ties to the Uribe administration and the Internal Displacement Monitoring Centre subsequently reported that twenty-one land restitution leaders were assassinated in $2011 .^{208}$

Even with a Victims and Land Restitution Law in force, the status of women as claimants is problematic in Colombia because women have not historically been title holders of property. Particularly in rural areas, property records tend to be poorly recorded, ambiguous, or missing altogether. ${ }^{209}$ If the land restitution provisions of the Victims and Land Restitution Law fall short due to problems with land titles and make it difficult for men to make their claims, then restitution almost certainly does not reach displaced women and children that are on their own. The result is that forced displacement has a disproportionately greater impact on women than on displaced men, and without the benefit of property rights, displaced women are left without legal standing, without the right to agency, and without the ability to organise and participate in their own advocacy. Moreover, displaced women have greater difficulty finding work than displaced men, which further exposes them to predatory crimes and sexual violence. ${ }^{210}$ Homeless, disaffected, and disenfranchised, they become easy targets for human traffickers.

The UN High Commission has expressed significant concern that the impact of the Victims and Land Restitution Law will be tempered if there is not a concerted effort to change the "attitudes and sensitivities" of State actors and some victims who have misinterpreted the Law as being one of providing assistance to victims to a law that "becomes a rights-based programme of empowerment in practice." 211

The bureaucracy created to deal with victim's claims, the Unit for Assistance and Comprehensive Reparations for Victims (UARIV), has been slow to handle complaints and process claims, and mistakes in the manner in which victims testimonies are taken and recorded impedes the delivery of justice. ${ }^{212}$ There is also concern that "violations other than displacement, such as rape or enforced disappearance and those violations committed by post-demobilization groups, will not be taken into account in practice." 213

The GOC has a duty, according to the UNHCR, to ensure that restitution and reparations to victims are not only are not only in the form economic compensation, but also account for the need of victims to rebuild their lives in a dignified manner and to restore the "social fabric of the affected communities." 214 At the same time, perpetrators of the armed conflict must face justice for acts that constitute human rights violations. When a State is unable or unwilling to meet these obligations to the civilian populations, the international community may convene ad hoc tribunals such

208 Internal Displacement Monitoring Centre, Internal Displacement Global Overview 2011: People Internally Displaced by Conflict and Violence 29, April 2012, available online at <internaldisplacement.org/publications/global-overview-2011> (accessed 10 September 2013).

209 Supra nt. 202.

210 Note 61, Global Overview 2011: People Internally Displaced by Conflict and Violence 57, Internal Displacement Monitoring Centre (April 2012).

211 UNHCR, Annual Report of the UNHCR on the situation of human rights in Colombia 5, 7 January 2013, available online at <ohchr.org/Documents/HRBodies/HRCouncil/RegularSession/Session22/AHRC-22-17-Add3_English.pdf $>$ (accessed 14 November 2013).

212 Note 64, Ann. Rep. of the UNHCR on the situation of human rights in Colombia 6, A/HRC/22/17/Add.3 (Jan. 7, 2013), available online <ohchr.org/Documents/HRBodies/HRCouncil/RegularSession/Session22/A-HRC-22-17Add3_English.pdf> (accessed 14 November 2013).

213 Ibid.

214 Ibid. 
as have been created for the former Yugoslavia and Rwanda. One international tribunal was recently convened in Kosovo to try a group of doctors involved in an elaborate organ trafficking ring based in the capital of Pristina. ${ }^{215}$ Prosecutors, headed by a Canadian, tried the case before a panel of judges from the European Union Rule of Law Mission in Kosovo sitting with a Kosovar judge, and won several convictions for human trafficking and organised crime. This is an important court proceeding that could become a model for international cooperation with the GOC in bringing human traffickers to account.

\section{IV.2. Legislation}

The Colombian government has enacted various domestic laws following a broader international legal framework for the protection of refugees to address the displacement crisis. According to Article 93 of the Colombian Constitution, rights included in the Constitution shall be interpreted in accordance with international human rights treaties ratified by Colombia; therefore, international treaties ratified by Colombia have constitutional rank within the Colombian system. ${ }^{216}$ While a recitation of the specific laws is unnecessary, the primary enactments are Law 387 of $1997^{217}$ and Decree 2569 of $2000,{ }^{218}$ and Decree 4503 of $2009,{ }^{219}$ which established the procedure and rules for determining refugee status under an Advisory Commission. Together these laws consists of three different phases for reparation and restitution: prevention and protection, urgent humanitarian action (by providing immediate aid during the first moments of refugee's arrivals, during which often the first cases of human trafficking take place), and socioeconomic stabilization. ${ }^{220}$

This legal framework was developed in the context of existing complex legal provisions intended to protect women from sexual violence and exploitation. Other legislation that embraces international law include Law 599 of $2000^{221}$ which protects women as a group, Law 800 of $2003^{222}$ which ratified the UN Convention against Transnational Organized Crime and the Additional Protocol to Prevent, Suppress and Punish Trafficking in Persons, Especially Women and Children, and Law 985 of $2005,{ }^{223}$ which incorporated an article into the Criminal Code pertaining to the trafficking of persons both within and beyond Colombian territory. ${ }^{224}$

215 The New Yorker News Desk, Schmidle, N., An Organ-Trafficking Conviction in Kosovo, 29 April 2013, available online at <newyorker.com/online/blogs/newsdesk/2013/04/an-organ-traffickingconviction-in-kosovo.html>, and NY Times, Bilefsky, D., 5 Are Convicted in Kosovo Organ Trafficking, 29 April 2013, Available online at <nytimes.com/2013/04/30/world/europe/in-kosovo-5-areconvicted-in-organ-trafficking.html $>$ (both accessed 10 September 2013).

216 See Colombian Constitution, art. 93.

217 Ley de 387 de 1997, Diario Oficial No. 43.091, of 24 July 1997.

218 Decreto 2569 de 2000, Diario Oficial No. 44263, of 19 December 2000.

219 Decreto 4503 de 2009, Diario Oficial No. 47538, of 19 November 2009.

220 Morales Martinez, J.D., and Fandino Martinez, Y.M., "Y Dios me hizo mujer': Desplazamiento forzado y vulnerabilidad de género", Revista de Estudos e Pesquisas sobre as Americas, Brasília, Vol. 2, N. 1 December 2008, available online at <seer.bce.unb.br/index.php/repam/article/view/ 1466/1099> (accessed 10 September 2013).

221 Ley 599 de 2000, Diario Oficial No. 44.097, of 24 July 2000.

222 Ley 800 de 2003, Diario Oficial No. 45.131, of 18 March 2003.

223 Ley 985 de 2005, Diario Oficial No. 46.015, of 29 August 2005.

224 As defined in Ley 985 de 2005, "exploitation means to obtain financial gain or other benefit for oneself or for another person, through the exploitation of the prostitution of others or other forms of sexual exploitation, forced labor or services, slavery or similar practices to slavery, servitude, exploitation of begging, servile marriage, organ removal, sex tourism and other forms of exploitation." The law also recognises that the consent of the victim to any form of exploitation "shall not constitute grounds for exemption to criminal responsibility." 
Despite such efforts to conform to international law and apply reforms in the criminal code, many victims of human trafficking are still unable to receive adequate protection. One of the things that need to be included in nations in conflict to be able to protect vulnerable groups from human trafficking is to develop a transitional justice framework that is both holistic and comprehensive, and one that provides for the protection of all human rights, including the economic, social, and cultural rights. Victims of human trafficking, especially in conflict situations, are often the vulnerable groups, the ones that have traditionally been discriminated against, the ones that have been traditionally stigmatised, and the ones that have been excluded from any state policy that will benefit them.

At this time in Colombia, a framework of transitional justice is elusive, particularly as impunity of perpetrators is prevalent, and the government seems indifferent to addressing violations of the constitutional and international legal rights of women. It is worth noting that in 2009, the Social Platform of Migration (HERMES) and members of the Colombian Congress initiated a project meant to address the refugee crisis due to the armed conflict, including the prevention of related human trafficking. However, the government objected to the effort and the provisions to combat human trafficking were dismantled during the legislative process. ${ }^{225}$

\section{IV.3. Constitutional Court Decisions Addressing Displacement}

The inability of the Colombian state to significantly improve the conditions of refugees has led the Colombian Constitutional Court to take action where the legislature has fallen short. In 2004, the Court issued a tutela, ${ }^{226} \mathrm{~T}-025 / 2004,{ }^{227}$ which determined that forced displacement constitutes "an unconstitutional state of affairs." The findings of the ruling were essentially as follows:

- There is massive and generalized violation of several constitutional rights that affect a significant number of persons;

- There is prolonged omission by the authorities in the exercise of their responsibilities to guarantee such rights;

- The adoption of unconstitutional practices has occurred as part of a process to guarantee the violated right;

225 For a thorough compilation of article son human trafficking in Colombia, see generally the collection of articles in "Diálogos Migrantes. Migración y Tráfico Humano", Rev. del Observatorio de Migraciones, No. 6 2011, available online at <observatoriodemigraciones.org/apc-aafiles/69e3909999fd8ec8018dd3f5d7dbdc5d/DMigrantes_No.6.pdf> (accessed 10 September 2013).

226 The tutela action is an important legal mechanism through which an individual requests immediate protection of his or her constitutional rights when a violation occurs. The tutela may be used in three situations: when constitutional rights are violated; when constitutional rights are seriously threatened; or when no other judicial mechanisms are available. See Rodríguez, C.A. et al., "Justice and Society in Colombia: A Sociolegal Análisis of Colombian Courts", in: Friedman, L.M. and Pérez-Perdomo, R., eds., Legal Culture in the Age of Globalization, Stanford: SUP 2003, 178. See also Constitución Política De La República de Colombia, art. 86 ("Toda persona tendrá acción de tutela para reclamar ante los jueces, en todo momento y lugar, mediante un procedimiento preferente y sumario, por sí misma o por quien actué a su nombre, la protección inmediata de sus derechos constitucionales fundamentales, cuando quiera que éstos resulten vulnerados o amenazados por la acción o la omisión de cualquier autoridad pública. La protección consistirá en una orden para que aquel respecto de quien se solicita la tutela, actúe o se abstenga de hacerlo. El fallo, que será de inmediato cumplimiento, podrá impugnarse ante el juez competente y, en todo caso, este lo remitirá a la Corte Constitucional para su eventual revisión.")

227 Sentencia No. T-025/04, the English translation of the decision is available online at <brookings.edu/ /media/Projects/idp/Colombia_T\%20025_2004.PDF> (accessed 21 August 2013). 
- There has been a failure to issue necessary legislative, administrative or budgetary means to prevent the violation of these rights. ${ }^{228}$

Additionally, in T-025/2004, the Court recognised that refugees face increased vulnerability to the violation of their rights, thus, meriting special attention. The court observed that "children, pregnant women, mothers with small children, female heads of the family, the disabled, and the elderly have a right to the protection and required assistance, and treatment that takes into account special needs." 229

The Constitutional Court then issued an additional finding, called an auto, which essentially is an interpretation of law. ${ }^{230}$ Auto 092 de 2008 attempted to articulate the vague mandate of $\mathrm{T}-025$ de 2004, and contained sweeping mandates. ${ }^{231}$ Most significantly, Auto 092 (a Constitutional Court Order Protecting Displaced Women and Girls) acknowledged the "disproportional impact, in both quantitative and qualitative terms, of the armed conflict and forced displacement on Colombian women," 232 specifically recognised the unique needs of displaced women and girls, and ordered the government to take comprehensive measures to protect the fundamental rights of internally displaced women and to prevent the disproportionate gender impact and sexual violence against women in conflict, during and following displacement. ${ }^{233}$ The Court found that 'sexual violence against women is a habitual practice that extends, systematically and invisibly, throughout the context of the armed conflict in Colombia'. Further, it emphasised that the Political Constitution and the international obligations the Colombian State has in areas of human rights and international humanitarian law mandate that women refugees have the "character of protected subjects", guaranteed by a reinforced constitutional protection. ${ }^{234}$

With Auto 092, the Constitutional Court identified eighteen gender dimensions of forced displacement in the context of armed conflict in Colombia. These eighteen dimensions include the heightened risks of displaced women to be victims of structural patterns of violence and gender discrimination such as sexual violence, ${ }^{235}$ including

${ }^{228}$ Morales Martinez, J.D. and Fandino Martinez, Y.F., "Y Dios me hizo mujer. Desplazamiento forzado y vulnerabilidad de género", 2:1 Revista de Estudos e Pesquisas sobre as Américas, 6(8) 2008.

229 Idem.

230 "An Auto is a decision that the Court issues on its own accord, exercising its inherent administrative powers or its jurisdiction over an open case." See Landau, D., "Political Institutions and Judicial Role in Comparative Constitutional Law”, 51 Harv. Int'l L.J. 319, (360) 2010, nt. 196.

231 Corte Constitucional, La Sala Segunda de Revisión, Auto 092 of 23 August 2008, (Colombia), available online at <www.internal-displacement.org/8025708F004CE90B/(httpDocuments)/ 2EC27FC9762FF0A8C125796000443284/ \$file/Auto+092+2008,+women.pdf> (accessed 22 August 2013).

232 Morales Martinez, J.D. and Fandino Martinez, Y.F., 2009, supra, nt. 236.

${ }^{233}$ Meertens, D., "Forced Displacement and Gender Justice in Colombia: Between Disproportional Effects of Violence and Historical Injustice", Case Studies on Transitional Justice and Displacement, Brooking-LSE Project on Internal Displacement, July 2012, in order of the International Center for Transitional Justice (ICTJ), 11, available online at $<$ ictj.org/sites/default/files/ICTJ-Brookings-Displacement-Gender-Colombia-CaseStudy-2012English.pdf $>$ (accessed 22 August 2013). Morales Martinez , J.D. \& Fandino Martinez, Y.F., 2009, supra, nt. 236.

234 According to the Profamilia Survey of 2005 , 8.1\% of displaced women have been raped by people other than their spouses or partners, among which $27 \%$ have been forced to have sex with strangers.

235 Original "auto" stating the following: "De acuerdo con la Encuesta de Profamilia de 2005, el 8.1\% de las mujeres desplazadas ha sido violada por personas distintas a su esposo o compañero, entre las cuales el $27 \%$ han sido forzadas a tener relaciones sexuales con desconocidos." Court decision available online at <www.corteconstitucional.gov.co/relatoria/autos/2008/a092-08.htm>. And Ojeda, G., and Murad, R., Salud sexual y reproductiva en zonas marginadas. Situación de las mujeres 
forced prostitution, sexual slavery and human trafficking for sexual exploitation. In addition, the Court found that the GOC's response to the refugee crisis had been insufficient to meet its constitutional and international duties, and that the existing elements of the public policy attending to forced displacement contained critical gaps that specifically affect displaced women who are left in a state of total helplessness. ${ }^{236}$ According to the resolutions of Auto 092, the Director of the Presidential Agency for Social Action and International Cooperation as well as the coordinator of the National System of Integral Attention to Displaced Population were tasked with implementing thirteen programs to assist victims displaced by the internal armed conflict. ${ }^{237}$ These programs include:

- Prevention of general disproportionate impact on the displaced

- Prevention of sexual violence and integral attention to victims

- Prevention of inter family and community violence and integral attention to victims

- Promotion of health and support for displaced women who are heads of households, the facilitation of access to productive employment opportunity and prevention of domestic labour exploitation

- Educational support for displaced women over 15 years of age

- Facilitation of access to land ownership

- Protection of the rights of displaced indigenous and Afrodescendent women

- Promotion of the participation of women in the prevention of violence against displaced women leaders due to their public visibility as labor, social, and human rights activists

- Elimination of barriers to the access of protection systems for displaced women ${ }^{238}$

desplazadas, 2005, Informe Profamilia, USAID, junio de 2006, Cuadro 7.1, 120, available online at $<$ measuredhs.com/pubs/pdf/FR172/FR172.pdf> (both accessed 14 November 2013).

236 "Internally-displaced women are at far greater risk of being sexually abused, raped or forced into prostitution because of their particular social, psychological and economic condition. According to statistics from the Ministry of Social Protection (Ministerio de Protección Social), 36\% of internallydisplaced women have been forced to have sexual relations with men they did not know." See Amnesty International, "Colombia: Scarred Bodies, Hidden Crimes: Sexual Violence against Women in the Armed Conflict", 12 October 2004, available online at <amnesty.org/en/library/info/AMR23/040/2004> (accessed 24 June 2013).

237 Human Rights Watch, "Rights Out of Reach, Obstacles to Health, Justice, and Protection for Displaced, Victims of Gender-Based Violence in Colombia", Report on developments in Colombia's laws, policies, and programs on rape and domestic violence, 14 November 2012, 30, available online at <hrw.org/reports/2012/11/14/rights-out-reach > (accessed 22 August 2013).

238 Translated from original text: Prevención del Impacto de Genero Desproporcionado del Desplazamiento, Prevención de la Violencia Sexual y de Atención Integral a sus Víctimas, Prevención de la Violencia Intrafamiliar y Comunitaria y de Atención Integral a sus Víctimas, Promoción de la Salud, Apoyo de las Mujeres Desplazadas que son Jefes de Hogar, de Facilitación del Acceso a Oportunidades Laborales y Productivas y de Prevención de la Explotación Domestica Laboral, Apoyo Educativo para las Mujeres Desplazadas Mayores de 15 Anos, Facilitación del Acceso a la Propiedad de la Tierra, Protección de los Derechos de las Mujeres Indígenas y Afro descendientes Desplazadas, Promoción de la Participación de la Mujer y de Prevención de la Violencia contra Las Mujeres Desplazadas Lideres o que adquieren Visibilidad Publica por sus Labores de Promoción Social, Cívica o de los Derechos Humanos, Acompañamiento Psicosocial, y Eliminación de las Barreras de Acceso al Sistema de Protección por las Mujeres Desplazadas, supra, nt. 244, pt. V.A.7.. 
The Constitutional Court's decision has been criticised for not going far enough to help displaced women achieve restitution and social justice. For example, the Court was careful in its language with regard to land restitution for women, phrasing the program for displaced women as facilitating access to land and not restitution of land, 'and even less to 'doing justice' to women victims of conflict'. 239

The State's response to the Court ruling did little to fortify the goals of transitional justice because instead of creating special provisions for women to regain the land taken from them, they were placed into a market-based program run by the Rural Development Institute where they must compete with others for land reassignments. "Although this program has reportedly improved displaced women's access to land through special schemes, the government's strongly selective procedures based on economic competitiveness do not guarantee restitution at all (and in fact, were not aimed at restitution) to displaced women who have lost their land." 240

With regard to displaced and demobilised children, in 2005 the Constitutional Court in Sentencia No. 203/05 addressed the problems attendant to reintegration of former child soldiers by writing that the institutional approach to demobilising child combatants should include socialisation, rehabilitation, education and protection. The Court wrote, 'It is a State obligation to promote the best interests of the child as well as the special protection and fundamental rights of minors, in their capacity as particularly vulnerable victims of the armed conflict'. Moreover, the Court found, "both Article 39 of the Convention on the Rights of the Child and its Optional Protocol as well as the various provisions in Article 3 common to the 1949 Geneva Conventions and in their 1977 Additional Protocol II bind the State to implement programs aimed at . . . promoting the eventual reincorporation of such minors into an ordinary civilian life in their communities of origin." ${ }^{241}$

In 2007, the Constitutional Court held, in Sentencia No. C-291/07, that the obligation to protect the special rights of children affected by armed conflict derives from the development of customary international humanitarian law applicable in internal armed conflicts, and is 'one of the fundamental guarantees stemming from the principle of humanity'. ${ }^{242}$

\section{Call for Innovation and International Engagement}

\section{V.1. Creation of Human Trafficking Task Forces}

In September 2003, the then President George W. Bush addressed human trafficking before the United Nations, declaring:

"There's a special evil in the abuse and exploitation of the most innocent and vulnerable. The victims of sex trade see little of life before they see the very worst of life-an underground of brutality and lonely fear. Those who create these victims and profit from their suffering must

239 Meertens, D., 2012, supra nt. 242.

240 Idem.

241 See International Committee of the Red Cross, "Colombia: Practice Relating to Rule 135. Children", available online at <icrc.org/customary-ihl/eng/docs/v2_cou_co_rule135> (accessed 1 June 2013). The ICRC report notes that the Court also held that "The mere participation of a child or adolescent in acts of violence committed by underage combatants will necessarily have grave psychological and social effects that demand an especially strong response from the State in terms of protection and rehabilitation, an objective to which determining the criminal responsibility of each minor and confronting the minor with the facts can contribute as well as the full implementation of the different steps of the process of reconciliation with the community, the society and the State."

242 Ibid. 
be severely punished. Those who patronize this industry debase themselves and deepen the misery of others. And governments that tolerate this trade are tolerating a form of slavery." 243

Following his UN address, President Bush allocated \$7.6 million in grants to federal and state law enforcement agencies to establish human trafficking task forces to 'aid in the identification and rescue of human trafficking victims'. ${ }^{244}$ Less than a year later, pilot task force coalitions comprised of federal, state and local law enforcement, and community-based organisations were established in Atlanta, Philadelphia, Phoenix, and Tampa to spearhead coalition-building best practices for other task force coalitions to follow in other cities around the country. ${ }^{245}$ Among the responsibilities given to these task forces was to establish training methods for law enforcement officers, conduct intensive community outreach, and to provide comprehensive assistance to victims. ${ }^{246}$

In addition to establishing task forces nationwide, the Department of Justice began holding nationwide training seminars and programs for law enforcement personnel, prosecutors, judges, social workers, victims' advocates, academics, business representatives, and faith-based organisations, among others, based on a carefully developed model curriculum that emphasises a victim-centred approach to finding and rescuing trafficking victims and investigating and prosecuting traffickers and abusers. The model curriculum became a uniform methodology of best training methods and investigative techniques for effectively combating human trafficking and related crimes nationwide. ${ }^{247}$

The success of human trafficking task forces are dependent on cooperation between local law enforcement and community-based organisations that are skilled at identifying trafficking victims during the course of "field operations and the delivery of social services." ${ }^{248}$ One of the most successful task forces has been based in Tampa Bay, Florida and is known as the Clearwater/Tampa Bay Area Task Force on Human Trafficking, founded in 2006 with a grant from the U.S. Department of Justice. Like all task force coalitions, the Clearwater/Tampa Bay Area Task Force's mission is to 'identify and rescue victims, create a coordinated law enforcement system to investigate and prosecute these crimes, and to deliver social, legal and immigration services to human trafficking victims in the Clearwater and Tampa Bay area'. ${ }^{249}$

Since the national task forces and coalitions were conceived in 2004 in the United States, a great deal has been learned about how to combat human trafficking, identify and rescue victims, bring traffickers and abusers to justice, and restore the lives of trafficking victims and their families. These organisations could serve as exceptional models for establishing similar task force organisations throughout Colombia to combat human trafficking. Key to the success of such task forces, however, would be

${ }^{243}$ U.S. Dept. of Justice, "Department Of Justice Announces Human Trafficking Task Force In The District Of Columbia And Grants For Law Enforcement To Fight Human Trafficking And Assist Victims", Press Release of 23 November 2004, available online at <justice.gov/opa/pr/2004/November/04_opa_760.htm> (accessed 22 August 2013).

244 Ibid.

245 U.S. Dept. of Justice, Bush Administration Hosts First National Training Conference to Combat Human Trafficking, Press Release of 16 July 2004) available online at <justice.gov/opa/pr/2004/July/04_ag_489.htm> (accessed 24 June 2013).

${ }^{246}$ Ibidem.

247 Ibidem.

248 U.S. Dept. of Justice Press Release, 2004, supra nt. 252.

249 See the Clearwater Task Force on Human Trafficking webpage, available at <catfht.org/index.php/about-us> (accessed 24 June 2013). 
establishing close working relationships between law enforcement and communitybased organisations. The challenge is that in Colombia there is a high level of distrust between law enforcement and community-based organisations, especially given the level of violence that has visited community-based organisations and their workers and the resulting impunity for perpetrators over the decades. Before any task force can be formed, steps must be taken to overcome the wariness that residents, social workers and community organisers in affected communities hold toward a state authority that has been largely absent in their communities, has not honored past commitments, and "may prove unable to protect them" from groups that may oppose the creation of task forces. ${ }^{250}$ Then, in order to achieve the level of cooperation between law enforcement and community-based organisations that is critical to the success of human trafficking task forces, clearly defined and transparent common goals must be established. This may mean taking baby steps toward better cooperation by working on issues that are not too overwhelming, like, for example, promoting outreach projects to education communities about human trafficking.

Representatives from the task forces in the United States could provide valuable guidance to Colombian authorities in setting up pilot task forces, following a similar roadmap to that used by the Department of Justice in the United States during the last decade. My personal involvement with task force groups over the last ten years is that the law enforcement officers are passionate about their work in fighting human trafficking, and the community-based and faith-based organisations view rescuing and restoring victims as a special calling. If the GOC would be willing to introduce task force models first into major cities, like for instance, Bogotá, Medellín, Cali, and Cartagena, it would not be difficult to bring experts, including Spanish-speaking experts from the United States, to assist in setting up the organisations.

From within the regional task forces, an international organisation composed of law enforcement investigators of human trafficking crimes has emerged that could provide critical support to law enforcement counterparts in Colombia. This organisation, the International Association of Human Trafficking Investigators (IAHTI), has the capacity to share their best practices and intelligence for improving the capacity of law enforcement organisations to combat all forms of human trafficking. The mission of IAHTI is straight forward-to work with law enforcement and prosecutors throughout the world to provide the most up-to-date human trafficking training, investigative techniques and technology. ${ }^{251}$ Engaging an organisation like IAHTI in pilot programs in just one or two Colombian cities would be to plant the seeds to develop new networks of law enforcement officers and prosecutors who could develop special expertise, and more importantly, special uniform expertise on combating human trafficking. Moreover, by creating a group of specialists in law enforcement, the GOC would be creating a sense of professionalism and a higher commitment to ethical conduct among an elite group of law enforcement personnel, which would go a long way to improving relations between law enforcement and the communities they serve.

Law enforcement must also understand how community-based organisations go about identifying, rescuing, and advocating for human trafficking victims. There are many organisations with vast international experience capable of going into Colombia

${ }^{250}$ Isacson, A. and Poe, A., "After Plan Colombia: Evaluating "Integrated Action," the Next Phase of U.S. Assistance", Report for the Center for International_Policy, December 2009, available online at $<$ justf.org/content/after-plan-colombia> (accessed 22 August 2013).

${ }^{251}$ See the International Association of Human Trafficking Investigators webpage at <iahti.org> (accessed 24 June 2013). 
to work closely with law enforcement to train officers and investigators on how to treat trafficking victims, to preserve the dignity of victims, and to prepare them to take an active role in investigating and prosecuting their traffickers and abusers. Among the groups best skilled at such a task is La Strada International (LSI), based in Eastern Europe. ${ }^{252}$ LSI's mission has long been to prevent human trafficking, especially trafficking of women, and their mission is to improve the position of women in society, to protect their universal rights, and to protect them from violence and abuse. LSI would have the resources, membership, and experience to go into Colombia to work on capacity building among community-based organisations and work to educate law enforcement and judicial officers about the trafficking of women and best practices for preserving their human rights.

\section{V.2. Creation of a Human Trafficking Court}

Establishing a specialised court in Colombia to work in concert with specially trained police and prosecutor teams may be the best solution for gaining leverage on human traffickers. Such a court and investigation resources would have jurisdiction over all forms of human trafficking that occur on Colombian soil, and would be based on models in use and evolving in other countries.

For example, in the United Arab Emirates, beginning around 2007, the Dubai Police force established an anti-human trafficking unit, followed soon after by a similar special unit in the Dubai public prosecutor's office. ${ }^{253}$ By 2010 the UAE had established a specialised court to process human trafficking cases to help victims of sexual exploitation. ${ }^{254}$ The court was established because human trafficking crimes put unique responsibilities on the UAE government there. One is that the government bears the costs for caring for the victims while the case is adjudicated, which is obviously costly, and the other is that trafficking cases fall under the UAE's law on combating crimes of human trafficking, in addition to international agreements the government has entered into with other nations. ${ }^{255}$ Judge Ahmed Ibrahim Saif said the purpose of the court was to hear cases more quickly, to 'protect the interests of the victims and to mitigate the damage inflicted upon them due to such crimes', and to assist victims in returning to their homelands. ${ }^{256}$ Before the creation of the human trafficking court, cases involving human trafficking could take up to three months in the criminal court system where the adjudication process involved several hearings and adjournments before reaching a verdict. ${ }^{257}$

${ }^{252}$ La Strada International comprises a network of eight member organisations in Belarus, Bulgaria, Czech Republic, Macedonia, Moldova, The Netherlands, Poland and Ukraine, and an international secretariat based in Amsterdam, The Netherlands. See the La Strada International webpage, available at <lastradainternational.org $>$ (accessed 4 June 2013).

${ }^{253}$ Mustafa, A., Special Dubai Court to Ease Trafficking Victims' Ordeal, Dubai: the National (UAE), 10 Nov 2010, available online at <thenational.ae/news/uae-news/courts/special-dubai-court-toease-trafficking-victims-ordeal $>$ (accessed 22 August 2013).

${ }^{254}$ Emirates 24/7, "Dubai to Set Up Special Human Trafficking Court", 25 October 2010, available online at <emirates247.com/news/emirates/dubai-to-set-up-special-human-trafficking-court-201010-25-1.308704> (accessed 22 August 2013).

${ }^{255}$ UAE Federal Law No. 51 Combating Human Trafficking Crimes, Law of 9 November 2006, available online at the website of the National Committee to Combat Human Trafficking, $<$ nccht.gov.ae/en/menu/index.aspx?mnu=cat\&PriMenuID=14\&CatID=10> (accessed 22 August 2013).

${ }^{256}$ Emirates 24/7, 2010, supra nt. 263.

257 Al Sadafy, M. "Special Panel to Handle Human Trafficking Cases", for Emirates247.com, 10 November 2010, available online at <emirates247.com/news/emirates/special-panel-to-handlehuman-trafficking-cases-2010-11-10-1.315808> (accessed 22 August 2013). 
The court is composed of a three-judge panel convening to hear cases twice weekly, and care is taken to ensure a suspect's right to a fair trial, including assigning defence lawyers to help move the adjudication process along. However, the court hears cases only involving sex trafficking and not labour trafficking. Yet, this effort constitutes an important step toward creating a court of special jurisdiction that could serve as a model for a country like Colombia to follow.

\section{V.2.1. How to Fund and Sustain the Court}

If a similar human trafficking (HT) court could be established in Colombia, the first order of business for the government would be to find sustainable funding. This funding could come from various sources, including a "sin tax" or annual licensing fees collected from businesses that are connected to human trafficking activities, namely casinos and night clubs, escort businesses and sex tourism agencies, the hotel and hospitality industry, and agribusiness, which employs a significant number of trafficked workers particularly in Colombia's highly lucrative flower industry. Additional funding for the HT courts could also come from set-asides from demobilisation and reintegration programs. Law enforcement special anti-trafficking units that work directly with the HT courts would be funded by an additional tax for public services that most Colombian citizens already pay as part of property and income taxes. A modest tax could also be attached to highway tolls and gasoline taxes because human trafficking is a commercial enterprise that moves along highway corridors throughout the national territory. All Colombians need to become stakeholders in the fight against human trafficking, which means having to pay something into the government coffers to fund the apparatus necessary to bring special resources to bear to control human trafficking, rescue and restore victims, and punish traffickers.

\section{V.2.2. Jurisdiction and Judicial Procedures}

The HT courts would be part of the justice ministry, with judicial appointments made by the justice minister. Judges would have term appointments and their renewal would be based on performance measures established with the assistance of international consultations and foreign judicial experts. Judges, court staff, and law enforcement investigators would be required to participate in continuing education programs, and law schools could develop a specialisation in human trafficking adjudication for both law students and for continuing legal education.

The HT courts could be based in the capitals of each Colombian department. Judges could also "ride circuits" throughout their jurisdiction to hear cases in the municipalities where human trafficking crimes occur. This has been a practice in the courts of first instance in Colombia for decades and could help control administrative costs because it is easier for the judges and clerical staff to travel to where the cases originate than to pay to bring defendants, victims, witnesses, and their lawyers to a central court location. On the other hand, sending judges out to ride circuit to hear human trafficking cases would pose a security and safety concern for the welfare of the judges in cases where the defendants are tied to organised crime and illegal armed groups, in which case a secure centralised court would make more sense.

Court rules pertaining to procedure, evidence, and plea-bargaining must be drafted to ensure that justice is swift and certain, and penalties must include jail time and fines, as well as the possibility of civil remedies following conviction. Again, this is where experts from the international legal community could be crucial to establishing a specialised court system that functions well and upholds the law. 
Fast-track rules of procedure and specialised rules of evidence would need to be promulgated to ensure that human trafficking cases do not get back-logged in the manner in which so many criminal and civil cases are mired in delay in the current Colombian court system. The UNHCR has noted in 2013 that, 'the vast majority of investigations into crimes against human rights defenders are in the preliminary stages in the Attorney General's Office, partly because prosecutors with high caseloads tend to favour less complex cases'. ${ }^{258}$ This is due in part to a confusing implementation of judicial reforms and a complex conversion from the inquisitorial system of Colombia's civil law tradition to a hybrid accusatory criminal justice system based on an AngloAmerican model that was imposed on Colombia in the last decade under judicial reform/delivery of justice projects funded by Plan Colombia. ${ }^{259}$

Courts' rules would have to be devised by a judicial rule-making commission comprised of judges, prosecutors, defence lawyers, academics, and experts from rulemaking commissions in the United States, especially because the Colombian accusatory system, which is now in place, was designed largely by legal consultants from the United States. Attention would be focused on the protection of witnesses and victims, production and preservation of evidence for trial, pre-trial motions, procedures during trial, jury instructions (if jurors were to be part of a human trafficking court), sentencing guidelines, and post-trial motions and appeals.

\section{V.3. Involve the International Community to Advise and Monitor}

Over the last several decades, the international community has invested many millions of dollars in aid to fortify, reform, and sustain the Colombian judiciary and provide relief to displaced trafficking victims. ${ }^{260} \mathrm{Much}$ of the funding comes from nongovernmental organisations while a very small amount is provided by the GOC. In 2012, for example, the US State Department reported that the GOC provided less than $\$ 50,000$ to one international organisation to assist trafficking victims within Colombia and to Colombian nationals requiring emergency assistance abroad. ${ }^{261}$ Only a paltry ten victims received assistance from government-funded organisations, and while the GOC claimed its program for assisting trafficking victims was successful, the nongovernmental organisations 'asserted that the referral process did not work well in practice, and that funding was insufficient and inefficiently distributed' ${ }^{262}$ In fact, one non-governmental organisation opened a shelter for trafficking victims, but it soon

258 Office of the United Nations High Commissioner for Human Rights, "Annual report of the United Nations High Commissioner for Human Rights", reference no. A/HRC/22/17/Add.3, 7 January 2013, $17, \quad$ available online $\quad$ at <ohchr.org/Documents/HRBodies/HRCouncil/RegularSession/Session22/A-HRC-22-17-

Add3_English.pdf $>$ (accessed 22 August 2013).

259 For a thorough analysis of the Colombian judicial reform efforts, see Nagle, L.E., "Process Issues of Colombia's New Accusatory System", Southwestern Journal of Law and Trade in the Americas, (14) 2007-2008, 223-287.

260 The international community has also made its share of empty commitments in the form of declarations such as the Condemnation of Terrorist Acts in Colombia issued by the Organization of American States in February 2003, that recognised the damage that terrorism has done to Colombia and its people and the link between these acts and drug trafficking, money laundering, arms trafficking, and "other forms of transnational organized crime," but did little else; see Permanent Council of the OAS, "Condemnation of Terrorist Acts in Colombia", 12 February 2003, ref. no. CP/RES. 837 (1354/03), available online at <oas.org/oaspage/terrorismo/rescoen1.htm> (accessed 28 June 2013).

261 U.S. Dept. of State, Trafficking in Persons Report - Colombia, 19 June 2012, available online at $<$ refworld.org/docid/4fe30cd75.html> (accessed 22 August 2013).

262 Ibid. 
closed due to lack of funding. This is a prime example of the need to have long-term funding and monitoring of programs developed to assist trafficking victims, and it is incumbent upon the international organisations and States providing aid to keep a close watch on how the money is spent in Colombia.

The just-released 2013 State Department Report for Colombia presents a perplexing series of contradictions to international monitoring organisations trying to understand what is happening in Colombia. Colombia remains a Tier 1 country in the fight against human trafficking for 2013. A Tier 1 classification means that a government has acknowledged that human trafficking exists in its territory, has addressed the problem, and meets the minimum standards set forth in the federal Victims of Trafficking and Violence Protection Act (TVPA). ${ }^{263}$ In bestowing Tier 1 status on Colombia, the State Department asserts that things are looking up in Colombia:

The Government of Colombia fully complies with the minimum standards for the elimination of trafficking. Authorities continued to undertake awareness campaigns and law enforcement efforts, prosecuting transnational sex trafficking cases and opening a significant number of investigations. ${ }^{264}$

Yet, Colombian trafficking victims continue to be found in forced labour in mining, agriculture and domestic service, in direct violation of the UN Convention Concerning the Prohibition and Immediate Action for the Elimination of the Worst Forms of Child Labour, ${ }^{265}$ and women and children continue to be trafficked into forced sexual servitude, and the State Department even states that sex trafficking "remains a significant problem" in Colombia. ${ }^{266}$ Moreover, Colombia remains a destination country for Ecuadorian children trafficked for sex and forced servitude, and Colombia has emerged as a major destination in the western hemisphere for sex tourism in which human trafficking plays a key role. ${ }^{267}$

263 Victims of Trafficking and Violence Protection Act of 2000, 28 October 2000, Public Law 106-386, reference 22 USC 7101. Section 104 of the Act sets forth the criteria for assessing to what extent a country is combating human trafficking. The tier system is devised from these criteria. For a complete explanation of the Tier system, see U.S. Dept. of State, Office to Monitor and Combat Trafficking in Persons, "Tiers: Placement, Guide, and Penalties for Tier 3 Countries", 2011, $<$ state.gov/j/tip/rls/tiprpt/2011/164221.htm> (accessed 24 June 2013).

264 U.S. Dept. of State, "Trafficking in Persons Report. Country Narratives: A-C", June 2013, 131, available online at <state.gov/j/tip/rls/tiprpt/2013/index.htm> (accessed 22 August 2013).

265 Convention concerning the Prohibition and Immediate Action for the Elimination of the Worst Forms of Child Labour, art. 3(a), June 17, 1999, 38 I.L.M. 1207. Colombia ratified on January 28, 2005.

266 U.S. Dept. of State, supra nt. 274. The Narratives report on Colombia paints a discouraging picture for Colombian citizens who continue to be targeted by human traffickers. Groups at high risk for internal trafficking include internally displaced persons, Afro-Colombians, indigenous communities, and relatives of members of criminal organisations. Ecuadorian children are subjected to forced labour and sex trafficking in Colombia, and Colombian children are exploited through forced begging in urban areas. Illegal armed groups forcibly recruit children to serve as combatants, to cultivate illegal narcotics, or to be exploited in prostitution. Members of gangs and organised criminal networks force vulnerable Colombians, including displaced persons, into sex trafficking and forced labour, particularly in the sale and transportation of illegal narcotics. Colombia is a destination for foreign child sex tourists from the United States, Europe, and other South American countries.

267 Curiously, Colombia is one of a few States that is not a party to the Supplementary Convention on the Abolition of Slavery, the Slave Trade and Institutions and Practices Similar to Slavery, 7 September 1956, art. 1(d), 18 U.S.T. 3201, 226 U.N.T.S. 3, which entered into force on 30 April 
The State Department says that the GOC has opened a significant number of investigations, but what are the actual numbers? The State Department also notes that the GOC has yet to enact a pending victim assistance decree from 2005, and that identifying labour and sex trafficking victims remains a problem for Colombian authorities. A reasonable observer can only wonder what the US State Department uses as a measurement given overwhelming evidence that the trafficking situation in Colombia is out of control and getting worse. How is Tier 1 status possible, and if Colombia is the Tier 1 standard by which other countries are judged, one wonders how much worse is the human trafficking problem in Tier 2 and 3 countries?

This assessment raises more questions than it provides details, and it suggests that a wall of obfuscation persists in Colombia such that international monitoring is impeded by a bureaucracy that has issues with transparency and accountability. This is the conclusion I reached during a fact-finding trip to Colombia in summer 2012 to do research on the Colombian government's efforts to assist displaced trafficking victims. On a visit to the office of the director for human rights in Medellín, no one working there seemed to have any idea what they were doing. It became an exercise in futility to meet with anyone in authority to discuss human trafficking and the plight of the displaced in Medellín. I was sent first to one office, only to be told I was in the wrong office and that I should go to another office. I went there and was told that the official I could see was not available and to go to another office to make an appointment. I went to make the appointment and was told that appointments were not made there and to go to another office. Meanwhile, I observed that the staff appeared to be doing little more than shuffling papers and talking on their cellphones over personal business and gathering up in small groups to go out for morning coffee. I was left with the distinct impression that the government efforts to fight human trafficking and assist displaced trafficking victims are woefully inept or intentionally designed to accomplish nothing. If I was there as a former Colombian judge, as a researcher from the United States, as a native speaker of the language, and in my own home town, and I was unable to get past a receptionist to speak to an official who could answer a few questions, then how are international monitoring organisations able to do their jobs in Colombia? Or could it be that I received no attention or assistance precisely because I am a native Colombian? Had I been a "gringo" researcher going the office, would my reception have been completely different? Would the officials have rolled out the dogand-pony show to demonstrate to the foreign monitors that the Colombian government is on top of the situation and vigilant in its fight against human trafficking? I realise that this unfortunate experience did not lead to a very scientific explanation of what is occurring in Colombia, but in speaking to several Colombian academics, law enforcement officials, human rights lawyers, and social workers in Colombia about the level of human trafficking and the impact of human trafficking on displaced people, it became apparent that their experience with the government mirrors my own. For Colombians not working inside the "system", there is basically no access to the officials who are supposed to be fixing the problems and there appears to be very little motivation to alter the status quo in the government apparatus. The attitude I felt in my dealings with the human rights office tasked with combating human trafficking was one of indifference at the least, and would suggest that as long as a minimum level of results is attained each year, as long as a little bit is accomplished to show that the GOC is doing something about the problem, then it is

1957. One could argue that even though Colombia is not a party, a convention having a large number of parties and in forced for a significant amount of time becomes customary international law, which would make Colombia subject to this Supplementary Convention. 
taken for granted that foreign government aid will keep rolling in year after year and that an entire "army" of bureaucrats will continue to keep jobs that seem to be meaningless and there for nothing more than show. Again, one can only wonder what my reception the office would have been had I been accompanied by foreign monitors and let them do the talking. My conclusion to this unfortunate episode is that foreign monitoring needs not only to be very diligent and persistent, but must also be more than willing to scratch far below the patina of the official presentations and facts and figures presented during fact-finding visits. Foreign monitors must be cognisant that what they may see and hear and experience is possibly far different than what a Colombian sees and hears.

\section{V.3.1. International Organisations and Non-Governmental Organisations}

In an effort to combat human trafficking, Colombia and Peru have partnered with various agencies including the International Organization for Migration (IOM) and the United Nations Office of Drug and Crimes (UNODC). These international organisations have provided much needed education to law enforcement and government officials in both countries. Additionally, IOM and UNODC have worked closely with the governments of each to develop different types of prevention measures. In conjunction with the UNODC, the Colombian government created a special police force, the Division of Sexual Crimes, specifically trained to address the crimes of smuggling migrants and human trafficking. Along with specially trained police, the government has trained workers within all parts of the justice system and has even developed a National Unit of Human Rights within the public prosecutor's office, the focus of which is dealing with cases of trafficking in persons. While training police and educating government officials are integral to the prevention and prosecution of human trafficking, raising awareness among citizens is also vital.

An extensive list of national and international non-government organisations dedicated to combating human trafficking can be found with hyperlinks to those organisations on Wikipedia. ${ }^{268}$ There are now dozens of organisations working worldwide to address specific aspects of human trafficking. Many of the organisations are well-funded and have experts well trained and prepared to travel to Colombia, often on modest budgets, to offer training on best practices for combating human trafficking, as well as to serve in a monitoring capacity of human trafficking programs in place in Colombia and offer recommendations for improving those programs.

Among the most well-established organisations that could offer significant technical expertise and advice are the Coalition Against Trafficking in Women, Global Alliance Against Trafficking in Women, La Strada International Association, and Polaris Project. Many of these organisations have a global footprint and networks. In addition to non-governmental organisations, several universities have established centres dedicated to combating human trafficking. Two of the most prominent academic centres in the United States are the Protection Project, based at Johns Hopkins University, which has been at the forefront of opposing human trafficking as

268 This is by no means a complete list, but it represents a reasonable point of embarkation for many reputable and capable human trafficking organisations. See Wikipedia, "List of organizations opposing human trafficking", available online at <en.wikipedia.org/wiki/List_of_organizations_opposing_human_trafficking> (accessed 24 June 2013). 
a human rights violation since $1994,{ }^{269}$ and the Center for the Advancement of Human Rights, at Florida State University, which plays a leading role among 'U.S. universities in conducting research, training, and victim advocacy aimed at combating modern slavery'. ${ }^{270}$ The Protection Project has one of the largest databases of country reports tracking human trafficking issues worldwide, and one the organisation's primary areas of work is in developing and presenting capacity-building programs for non-governmental practitioners and government officials. The programs engage 'representatives of international organisations in bringing international mechanisms of human rights protection closer to those who need them most'. ${ }^{271}$

The GOC and the non-governmental and community-based organisations dedicated to fighting human trafficking and improving the conditions of displaced women and children have a great many resources around the world to partner with in order to achieve many of the goals that the government is currently unable to reach or sustain.

\section{V.3.2. Involvement of United States Expertise}

In 2013, the State Justice Institute of the United States Department of Justice, announced funding of a Strategic Initiatives Grant to the Center for Public Policy Studies, the National Judicial College, and the Center for Court Innovation that is focused on four strategic points: 1) increasing understanding and awareness about the challenges faced by state courts in dealing with cases involving trafficking victims and their families, and traffickers; 2) developing and testing state and local approaches for assessing and addressing the impact of human trafficking victims and defendants in the state courts; 3) enhancing state and local court capacity to improve court services affected by human trafficking-related cases processing demands; and 4) building effective national, state, and local partnerships for addressing the impacts of human trafficking case processing in the state courts. ${ }^{272}$

${ }^{269}$ See the website of the Protection Project, available at <protectionproject.org> (accessed 26 June 2013).

270 See the website of the Center for the Advancement of Human Rights at $<$ cahr.fsu.edu/sub_category/HumanRight_projects.html> (accessed June 26 2013).

271 The Protection Project, "Technical Assistance/Capacity Building", available online at <protectionproject.org/activities/ta-capacity-building> (accessed 26 June 2013).

272 State Justice Institute, "Human Trafficking and State Courts Collaborative", Strategic Initiatives Grant announcement, available online at <sji.gov/trafficking.php> (accessed 10 June 2013). The Collaborative will result in a variety of products benefiting the state courts, including:

- A comprehensive resource inventory of background information about the demographics, scope, dynamics, and implications for the courts and justice system of various forms of human trafficking;

- A measurement framework that includes measures and tools for monitoring the impacts of human trafficking case processing in the state courts;

- Summary of changes in federal and state trafficking law, policy, and practice that might better serve the interests of the state courts;

- A human trafficking and state courts web-based resource network and clearinghouse for judges and court personnel;

- A best practices toolkit for jurisdictions interested in establishing a specialised prostitution/trafficking court;

- A series of bench cards targeting human trafficking-related issues;

- $\quad$ Best practice guidelines;

- Model planning and technical assistance process and supporting materials;

- Training on human trafficking via 12 courses for judges;

- Intensive technical assistance in six jurisdictions, and proven nationally applicable technical assistance approaches; and

- $\quad$ Published articles in various court periodicals about the project and the issue in general. 
This is an important development in creating a specialised human trafficking court system for Colombia because the United States already has a well-established rule of law and judicial reform framework operating in Colombia that resulted from the implementation of democracy and national building programs under Plan Colombia during the last decade and can play a critical role in helping Colombia to create human trafficking courts. The resources, research and experience in the United States will establish of pool of experts that could then go to Colombia and help establish best practices for establishing, funding and administering a specialised court.

\section{V.3.3. Making Colombia a Model for Other Countries}

Establishing a functioning and funded apparatus in the judicial branch, providing funding for special task forces in law enforcement to combat trafficking, and calling upon the private sector to become stakeholders in finding permanent solutions of displacements can all help Colombia to meet its international obligations. Yet, Colombia's international obligations do not entail only compliance with the international instruments to which it is a signatory. Rather, the GOCs international obligations extend to providing assistance outside Colombia to other nations struggling with similar issues of transitional justice. Colombia can in many ways be a crucible for devising best practices and developing a cadre of experts who can use their experiences and skills to effect change elsewhere. Colombian authorities, academics, non-governmental organisations, and practitioners should be encouraged to go beyond Colombia to establish a regional framework for training and implementing HT courts, special prosecutors, and law enforcement task forces (including those working with support from the private/corporate sector) throughout Latin America. They can play a role in relieving conditions in places like Ecuador and Panama where so many displaced Colombians have fled and have continued to be victimised and abused.

\section{Conclusions}

Colombia is a nation trying to stand on its feet after decades of internal armed conflict and socio-political violence. The trafficking of human beings for sex and labour is a thriving business in Colombia as long as the conditions of displacement cause women and children to take desperate measures to survive, or are forced to remain living in conditions that render them fully exposed to exploitation and criminality. Human trafficking has served as an instrument of intimidation, domination and control of civilian populations, as a tool to remove people from their land, and as a means for illegal armed groups to amass illicit wealth.

There is also a troubling gap between Colombia's laws and the execution of its laws. In truth, Colombia has excellent laws. Most are carefully constructed, some elegantly so. The constitutional jurisprudence is often bold in it rulings on the constitutionality of Colombian law, and the Constitutional Block has integrated to constitutional rank many international treaties and conventions pertaining to international humanitarian law and human rights law.

But the gap between commitment and fulfilment of the law persists and is due to three reasons. First, there is a large difference between what appears in writing and how the law is applied in practice. The second reason, which is related to the first, is due in great part to the lack of economic resources. It takes money to enforce the laws, and Colombia, for many reasons, seems constantly short of money to fund its policies and programs. Either the money has been mismanaged, or it has been misused and siphoned away due to corruption. This is only speculation to take up at another time. The third reason is due to the discrimination and stigmatisation embedded in the culture of Colombia where the ruling elites continue to preserve at all costs the 
prerogatives of their station in life and care precious little for anyone living below their class level.

All Colombians must become stakeholders in the process of transitional justice by (1) elevating the value of all human life regardless of social background or racial heritage, and (2) by aggressively prosecuting and punishing the human traffickers and "endusers" that cause such social and emotional misery. The task may seem insurmountable, but the key may be as simplistic as asserting political will, compassion, and courage to effect change. Addressing the root causes that sustain the trafficking of humans in Colombia entails not only tackling the economic, political, and social conditions that put women and children in vulnerable positions, but also changing the national consciousness.

www.grojil.org 